Scholarship Repository

University of Minnesota Law School

Articles

Faculty Scholarship

2014

\title{
Why Crime Rates Are Falling Throughout the Western World
}

Michael Tonry

University of Minnesota Law School, tonry001@umn.edu

Follow this and additional works at: https://scholarship.law.umn.edu/faculty_articles

Part of the Law Commons

\section{Recommended Citation}

Michael Tonry, Why Crime Rates Are Falling Throughout the Western World, 43 CRIME \& JUST. 1 (2014), available at https://scholarship.law.umn.edu/faculty_articles/511.

This Article is brought to you for free and open access by the University of Minnesota Law School. It has been accepted for inclusion in the Faculty Scholarship collection by an authorized administrator of the Scholarship Repository. For more information, please contact lenzx009@umn.edu. 


\section{Why Crime Rates Are Falling throughout the Western World}

\section{AB S T RACT}

Crime rates have moved in parallel in Western societies since the late Middle Ages. Homicide rates declined from 20 to 100 per 100,000 population in western Europe to one per 100,000 in most Western countries by the beginning of the twentieth century. Crime rates in major cities and in countries fell from the early nineteenth century until the middle of the twentieth. From the 1960s to the 1990s, rates for violent and property crimes rose in all wealthy Western countries. Since then, rates in all have fallen precipitately for homicide, burglary, auto theft, and other property crimes. The patterns appear in both police and victimization data. Rates for nonlethal violence have fallen sharply in the English-speaking countries and parts of continental Europe. In other parts of Europe, nonlethal violence has been stable or increasing, but the data are probably wrong. Interacting changes in rates of reporting and recording and in cultural thresholds of tolerance of violence that occurred earlier in the English-speaking countries are the likeliest explanation for the appearance of crime rate increases. Diverse explanations have been offered for both the long- and short-term declines. Most agree that, whatever the explanations may be, they do not include direct effects of changes in policing or sanctioning policies.

Almost no one except a handful of academic specialists seems to have noticed that crime rates are falling throughout the Western world.

Electronically published October 29, 2014

Michael Tonry is professor of law and public policy, University of Minnesota. $\mathrm{He}$ is the grateful beneficiary of data, advice, and assistance from many people including Anthony N. Doob, Manuel Eisner, Mike Hough, Julian Roberts, Rossella Selmini, Tapio Lappi-Seppälä, and the late and sorely missed Hanns von Hofer. 
That is curious. It should be seen everywhere as good news. Fewer people are victimized. Fewer are arrested, prosecuted, convicted, and punished. Hospital emergency rooms handle fewer intentional injuries. Insurance companies compensate fewer losses. Politicians have less incentive to propose and policy makers to adopt severe policies aimed at pleasing, placating, or pacifying an anxious public.

No one has a really good explanation for why crime rates are falling. Since few people have noticed that they are, this is not entirely surprising. Why crime rates are falling may in any case be the wrong question. The better question may be, Why did crime rates rise in all developed Western countries during the 1960s, 1970s, and 1980s before peaking and turning downward? There is nearly incontestable evidence that homicide rates fell dramatically and more or less continuously from the late Middle Ages through the middle of the twentieth century (Eisner 2003; Spierenburg 2008, 2012; Muchembled 2011). Few historians question that rates for other crimes fell from the early nineteenth century to the middle of the twentieth (e.g., Gurr, Grabosky, and Hula 1977). Those findings support a hypothesis that the rising rates of recent decades were an anomaly. The centuries-long downward trend has been interrupted before by profound social and economic dislocations. Crime rates usually fall during wars, for example, rise for a short period afterward, and then resume long-term patterns (Archer and Gartner 1976, 1984; Gurr 1981, pp. 344-46). Well-known social and economic dislocations of recent decades affected all developed countries and may simply have caused another short-term disruption to the long-term trend.

My aims in this essay are to demonstrate that crime rates have moved in parallel in the English-speaking countries and western Europe since the 1960s and to assess the main explanations for why they rose in the 1970s and 1980s and fell afterward. ${ }^{1}$ The implications are important. One is that Western countries are much more closely linked in structural, social, and cultural ways than is commonly recognized. Many demographic patterns in recent decades have characterized most or all developed countries including rising life expectancies, female labor force participation, and income inequality and declining fertility, infant

${ }^{1}$ The "English-speaking countries and western Europe" are my primary focus. That lengthy phrase is mostly used in lead sentences. Proximate references to "countries" should be understood to refer to English-speaking countries and western Europe unless other countries or regions are explicitly mentioned. 
mortality, and marriage rates. It would be odd if crime trends were not also common. All Western countries (and many others) appear to march to the same distant drummers without realizing that is what they are doing.

A second implication is that many of the things that governments have done to reduce crime rates in recent decades have been largely epiphenomenal-normatively and politically important, and having major effects on many people's lives, but pretty much beside the point in terms of crime rates and patterns. It is at least a little parochial, for example, that the US National Academy of Sciences twice in recent years has sought to explain recent American crime trends primarily in terms of distinctively American developments such as mass imprisonment, policing initiatives, legalization of abortion, and reduction in children's exposure to lead paint (e.g., Goldberger and Rosenfeld 2008; Rosenfeld 2014).

Comparison of American and Canadian developments makes the parochialism clear. Canadian crime rate patterns have closely paralleled America's since 1960, but Canada's imprisonment patterns and criminal justice policies have been starkly different (Webster and Doob 2007). Since 1960, the Canadian imprisonment rate has fluctuated around 100 per 100,000 population, while America's rose from 150 per 100,000 in 1970 to 756 in 2007. Canadian agencies have not emphasized zero-tolerance and other aggressive forms of policing, and the Canadian Parliament did not enact three-strikes, truth-in-sentencing, and life-without-possibility-of-parole laws. Only in the last couple of years have significant mandatory minimum sentence laws been enacted; they do not, however, require sentences measured in decades and lifetimes and are meeting strong resistance from the appellate courts $(R$. v. Smickle, 2013 Ontario Court of Appeals 677 [CanLII]; R. v. Nur, 2013 Ontario Court of Appeals 678 [CanLII]; Doob and Webster 2013).

Yet crime rates moved in tandem. Figure 1 shows US and Canadian homicide, robbery, and imprisonment rates since 1960. The US imprisonment rate nearly quintupled; the Canadian rate barely changed. Homicide rates, however, moved almost in lockstep. Robbery trends also were closely similar. Whatever caused homicide rates in the two countries to change in parallel, it was something other than changes in imprisonment rates and sentencing laws. Yet both US National 


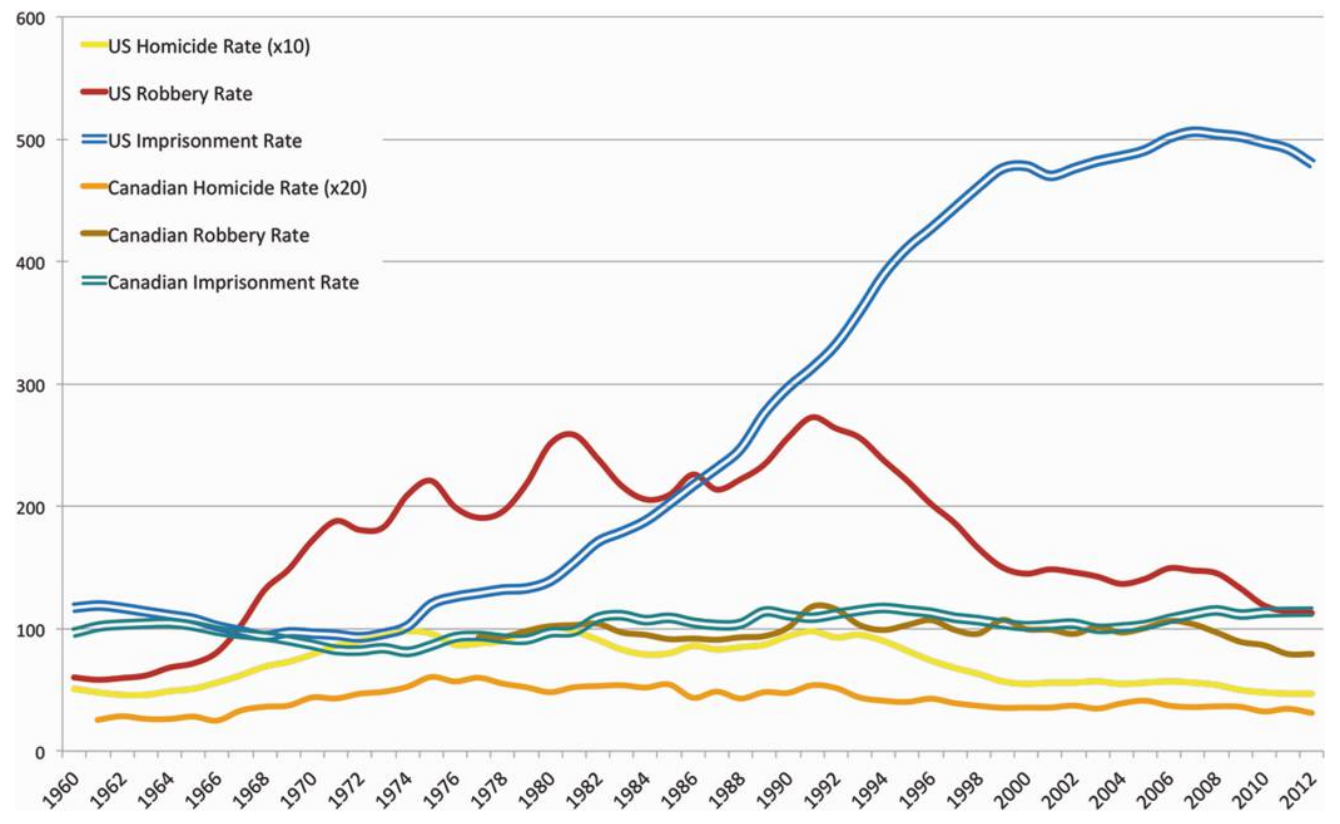

FIG. 1.-Imprisonment, homicide, and robbery rates per 100,000 population, Canada and United States, 1960-2012. Sources: Bureau of Justice Statistics; Statistics Canada; Walmsley (2013, table 1). US imprisonment rates do not include county jail inmates and understate total US imprisonment by approximately one-third. Reasonably reliable annual jail population data are unavailable before the 1980s. 
Academy of Sciences initiatives have sought to explain American crime trends as if the reasons for them are uniquely American.

Reasonable arguments can be made that recent drops in property crime rates were influenced by improved security technologies in motor vehicles, residences, and retail stores (e.g., van Dijk, Tseloni, and Farrell 2012b; Farrell, Tilly, and Tseloni 2014). Those developments may explain minor differences in trends between countries that adopted them more and less extensively or at different times, but all developed countries experienced substantial declines. Few plausible arguments can be made, however, that technological or crime control policy changes have caused sharp parallel declines in homicide and other violent and sexual offending. Something more fundamental is happening.

The evidence that crime rates have moved in parallel in Western countries between the 1960s and 1990s, with occasional lags in particular countries, is overwhelming. No informed person disagrees that homicide rates rose from various starting points in the 1950s and 1960s, peaked in the 1990s, and have since fallen (e.g., Eisner 2008, 2014). No informed person disagrees that nonviolent property crime rates-burglary, theft, motor vehicle theft-in all Western countries have been falling at least since the 1990s (van Dijk and Tseloni 2012). In some countries including the United States, there are good reasons from victimization data to believe that property crime declines began earlier. ${ }^{2}$ The declines in property crime rates are especially striking since they continued during the recessions that afflicted almost all Western countries beginning in 2008 and are continuing in many as these words are being written.

The disagreements concern trends in nonhomicidal violence and sexual offending since the early 1990s. In the English-speaking and some western European countries, both police and victimization data show that robbery, rape, and aggravated assault rates have fallen since the early to mid-1990s. In other western European countries, rates for nonhomicidal violence have not fallen since the early 1990s and in

${ }^{2}$ The Bureau of Justice Statistics (1994) published a report on victimization trends for 1973-92 (a major redesign of the National Crime Victimization Survey took effect the latter year). It showed that all forms of theft and household burglaries peaked in the early 1980s and then began the long-term trends that continue today. Rape and robbery peaked and began to fall in the mid-1980s but experienced small increases in the late 1980s, paralleling official data. Motor vehicle theft rates rose until the early 1990s. Only assault rates remained broadly stable. 
some have increased (e.g., Aebi and Linde 2010, 2012). The challenge is to explain those divergent patterns.

The explanation is that there is no divergence. The appearance of one is misleading. The incidence not only of homicide but of all violent crime is almost certainly falling in all developed Western countries, but this is obscured in three interrelated ways. First, victims have become more likely to report incidents to the police, but the timing of the increases varies between countries. Victimization surveys regularly ask respondents to indicate whether they reported incidents to the police. In the American national surveys, reporting rates for rape and domestic violence increased in the 1970s; after the mid-1980s, reporting rates for violent and sexual offenses increased substantially. Among the effects are that apparent increases in violent crime in the 1970s and 1980s were exaggerated and recent declines have been substantially underestimated. The most comprehensive analysis concludes that, when changes in victim reporting are taken into account, nonlethal serious violence decreased by 51 percent between 1991 and 2005. Police data indicate only a 27 percent decline (Baumer and Lauritsen 2010, p. 173). Similar patterns of increased levels of reporting to the police have been documented in England and Wales and Scandinavia, other places where annual victimization surveys have long been conducted (Chaplin, Flatley, and Smith 2011; Kivivuori 2014). As in the United States, apparent rate increases in official crime data have been exaggerated and decreases underestimated.

Second, net of changes in victim reporting, police recording practices have changed in ways that artificially increase crime rates. Partly this is the result of professionalization of police management and the related shift over 40 years from paper to electronic record keeping (Reiss 1992; Mastrofsky and Willis 2010). Recording rates for most crimes have increased, but more for some than for others. Domestic violence and sexual offenses are the paradigm cases, but other violent offenses are affected. No one who has lived through recent decades can fail to recognize that people in Western societies (at least) have become much less tolerant of intimate violence, violence against women, and sexual offenses generally (Pierotti 2013). Both for public relations reasons- to forestall criticism of police insensitivity-and because police are part of society and inevitably are affected by changing cultural attitudes, some kinds of incidents have become more likely to be officially recorded as crimes. 
In some countries, policy decisions have been made to increase recording rates. Two major recent changes were made in England and Wales. In 1998-99, counting rules were changed to record more minor, or "summary," offenses particularly for less serious violent crimes, frauds, and drug offenses. The Home Office estimated that the change increased crime statistics overall by 14 percent. However, there were wide variations by type of offense. Burglary and robbery were estimated to have been little affected but other violence against the person to have increased by 118 percent (Povey and Prime 1999). Hough, Mirrlees-Black, and Dale (2005, p. 28) later observed that the changes "would have taken several years to bed in ... [and] will have artificially inflated the count of crimes each year."

In 2002, the National Crime Recording Standard was introduced. England and Wales shifted from operating an "output" system in which police apply established criteria before recording incidents as crimes to an "input" system in which citizens' reports are taken at face value. The aim was to make the process more victim-oriented. The Home Office estimated that the change increased total crime rates by 10 percent in 2002/3, but as with the 1998-99 change, the effects varied between types of crime and were predicted to be especially significant for violent crimes (Simmons and Dodd 2003).

Third, cultural thresholds of tolerance have been changing since at least the 1960s. Behaviors now regarded as appropriately reported to police were in earlier times often regarded as unpleasant, undesirable, or socially unacceptable but not as criminal. Well-known examples include violence within domestic relationships, fights between acquaintances or drinking partners, and unwanted sexual touching in public. If the cultural meanings of such behaviors change over time, people at different times will use the same words to describe wrongful acts but mean different things. Here, too, domestic violence and sexual assaults are the paradigm cases. Had there been national victimization surveys in the 1960s, for example, respondents would have been much less likely than now to have thought of a blow from a husband, wife, or partner as an assault. Many victims of domestic violence or of bar fights would not have considered themselves to be crime victims and said "no" if asked if they had been assaulted. Many more such people in the 1980s and even more in the 2000s would have answered "yes." Issues of reporting and recording by definition would not have been raised in the earlier period for behaviors not then thought of as crimes. 
The social meaning of assault would have changed even though respondents themselves did not realize that they now considered behaviors to be criminal that earlier they would not have.

Similar changes are likely to have occurred concerning a wide range of sexual incidents especially including allegations of nonstranger rapes and attempted rapes in dating and acquaintance relationships. Feminists worked hard in the 1970s and 1980s to expand cultural conceptions and legal definitions of rape (Estrich 1987). No reasonable person can believe that their efforts were unsuccessful. Something similar occurred in relation to child abuse. Rates of reported child physical and sexual abuse increased enormously in the United States in the 1980s as the result of a succession of new laws requiring social workers, psychologists, nurses, doctors, and psychiatrists to report suspected incidents to the police (Garbarino 1989; Brosig and Kalichman 1992; Kalichman 1999). After the early 1990s, recorded rates of child physical and sexual abuse plummeted. Between 1992 and 2004, reported physical abuse fell by 43 percent and sexual abuse by 49 percent (Finkelhor and Jones 2006, fig. 1).

Taken together, changes in reporting, recording, and cultural thresholds of tolerance in recent decades have increased official crime rates substantially in all developed countries. Those increases are, however, likely to have occurred at different times in different places. Their effects on official crime rates were largely manifest in the United States and some other countries by the early and mid-1990s. In other places, including many western European countries, they occurred and are occurring later. It is difficult, for example, not to hypothesize that all three mechanisms are major causes of recent increases in rates of sexual offending and assaults in official data in the Scandinavian countries (Selmini and McElrath 2014). Sexual crimes are the targets of major social and political movements there and the subjects of important changes in criminal laws and practices (Skilbrei and Holmström 2011, 2013; Tham, Rönneling, and Rytterbro 2011). It would be astonishing if those initiatives had no effects on cultural attitudes, victim behavior, and police policies and practices.

In this essay, I provide evidence that supports the preceding assertions. Section I summarizes the literature concerning a many-centuries-long decline in homicide rates through the mid-1950s, after which rates increased in all developed Western countries. Section II documents declines in homicide rates beginning in the 1990s, declines in 
rates since then for all crimes in many countries, and discordant evidence of increases in violence rates in a few. Section III canvasses reasons why the apparent increases in violence rates in some countries are much more likely to be the effects of changes in recording, reporting, and cultural thresholds of tolerance than of real increases. Section IV briefly explores the underdeveloped literature that attempts to explain both long-term and recent falls in rates of property and violent crimes. The explanations are simultaneously simple and complex. The simple explanations center on secular subjects including situational crime prevention initiatives and target hardening, the bureaucratization of modern life, and cultural shifts that are denunciatory of crime and violence. The complex explanations concern interactions among cultural and secular changes that have influenced capacities for informal social control and individual self-control (Baumer and Wolff 2014; Eisner 2014).

\section{The Long-Term Decline in Crime Rates}

A massive body of evidence shows that crime rates have long been declining. For periods before the establishment of institutionalized systems of official data, mostly in the nineteenth and twentieth centuries, studies focus almost entirely on homicide. Work on periods after 1800 encompasses other violent and property crimes. In our time, official data series have been standardized and strengthened and in many countries have been augmented by data from representative national victimization surveys. Taken together, they show a steady decline of homicide rates over many centuries, declines in a wide range of offenses from the early nineteenth through the mid-twentieth century, rises in rates of all crimes during the 1970s and 1980s, and falls in property crimes and homicide since the early 1990s. The only disagreement concerns nonlethal violence and sexual offenses since the early 1990s.

There is nothing controversial about the assertion that homicide rates declined substantially and continuously after the late Middle Ages. Pioneering work by the Swiss historian Manuel Eisner (2003), recently popularized by Steven Pinker (2011), provides almost unchallengeable evidence through the nineteenth century. Work by American political scientist Ted Robert Gurr and others demonstrated remarkably parallel crime patterns in several Western countries from the early nineteenth century through the middle of the twentieth (Gurr et al. 1977). 
In a classic Crime and fustice article, Gurr (1981) offered evidence of a long-term decline in homicide rates in England between the thirteenth and twentieth centuries. For the earliest periods, Gurr calculated homicide rates for a few years or decades on the basis of work by English historians reporting data from coroners' and court records. From the beginning of the nineteenth century, he drew on data from official records. Figure 2, reprinted from Gurr's article, shows the results. The dots represent estimates based on individual studies; the solid line beginning in the nineteenth century is based on official records. Homicide rates averaged more than 20 per 100,000 in the thirteenth century, fell below 10 in the seventeenth century, and reached approximately the modern level of one per 100,000 in most western European countries in the nineteenth century. Writings on Finland (Ylikangas 1976), England (Cockburn 1991), Norway (Naess 1982), Sweden (Osterburg and Lindstrom 1988; Osterburg 1996), and the Netherlands (Spierenburg 1996) documented similar long-term patterns.

In another classic Crime and fustice article, Eisner (2003) documented centuries-long homicide declines in Europe beginning in some places in the fourteenth century. In the 1990s Eisner created the History of Homicide Database, on which he and most subsequent historians of long-term homicide trends have since relied. He was motivated by Gurr's showing of an apparent long-term decline in English homicide, evidence of similar patterns elsewhere, and speculation that something similar had happened throughout Europe. By 2003, Eisner's database contained 390 estimates of premodern homicide rates based on more than 90 publications. Figure 3, reprinted from Eisner's essay, shows the English data. It resembles figure 2 from Gurr but is based on many more studies and estimates. Separate figures for Scandinavia, the Netherlands and Belgium, Germany and Switzerland, and Italy showed comparable declines throughout Europe. The broad pattern was everywhere the same, but the timing varied: homicide rates in Scandinavia reached the contemporary level of one per 100,000 earliest, by 1800 , and in Italy reached that level last-only in the twentieth century. By 2014, the database included 823 estimates of homicide rates during the period before creation of official national data sets (Eisner 2014). Figure 4, using the updated database, shows long-term declining homicide rates for most regions in western Europe: the patterns are everywhere the same, but the timing varies. 


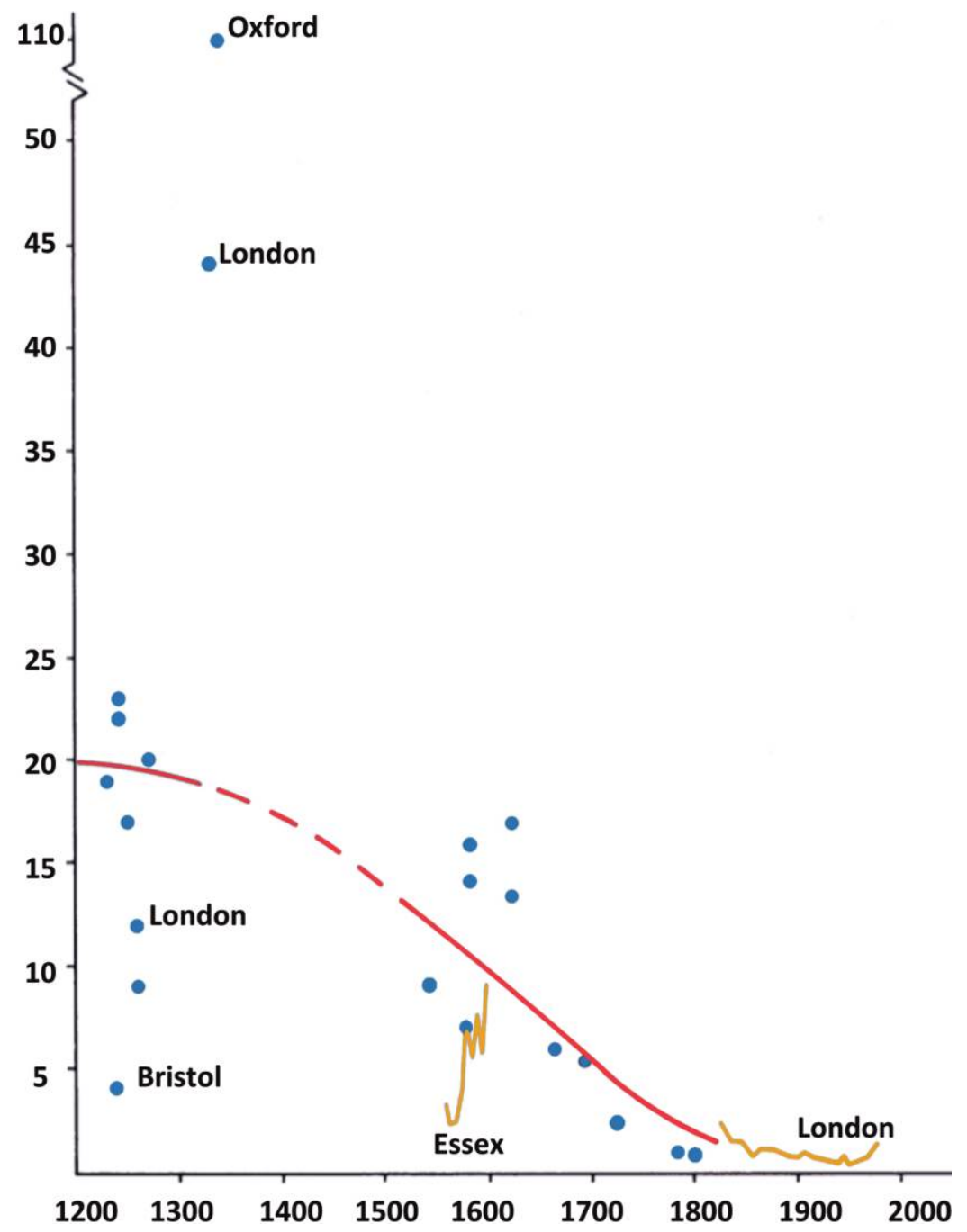

FIG. 2.-Homicide rates per 100,000 population, England, 1200-1980. Reprinted from Gurr (1981, p. 313, fig. 1). Each dot represents the estimated homicide rate for a city or county for periods ranging from several years to several decades. See Gurr (1981) for details on sources. 


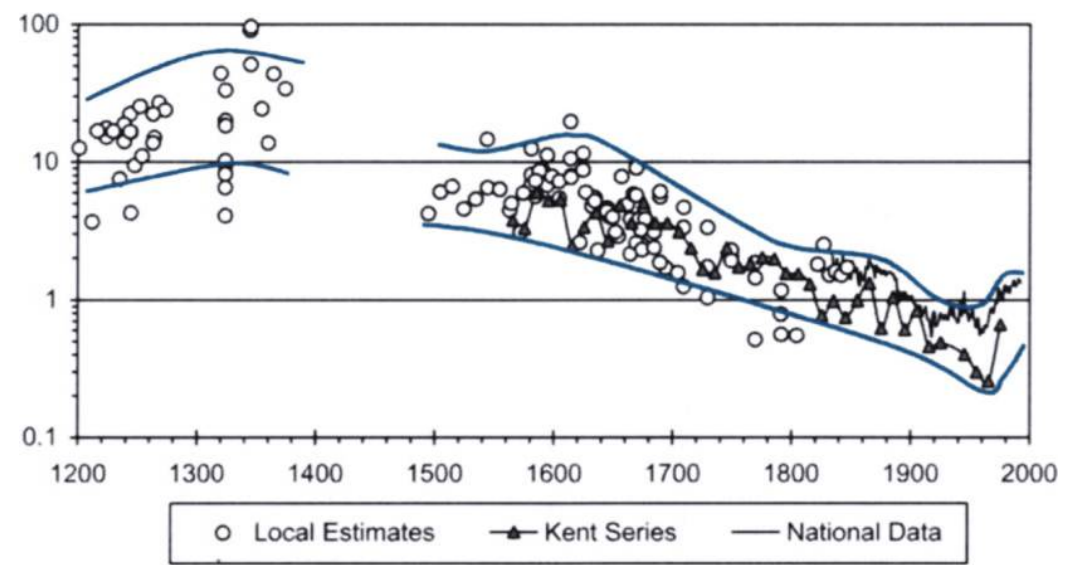

FIG. 3.-Homicide rates per 100,000 population, England, 1200-1990. Reprinted from Eisner (2003, p. 96, fig. 3). See Eisner (2003, 2014) for details on sources.

Gurr and colleagues had earlier looked at official data on crime in London, New South Wales (Sydney), and Stockholm and found that rates for all offenses declined substantially during the nineteenth and early twentieth centuries (Gurr et al. 1977). In England, which had the most extensive official record systems, rates of recorded crime, convictions, and imprisonment fell substantially. This was widely recognized in the late nineteenth century; French newspapers referred to it as the "English miracle" (Radzinowicz and Hood 1986). Zehr (1975, 1976) demonstrated a somewhat similar pattern for France.

American scholars writing in the 1980s and 1990s confirmed for the United States the pattern that Gurr and his colleagues had shown for London, Stockholm, and Sydney (e.g., Lane 1980, 1992; Monkkonen 1981). They described a "U-curve" of falling then rising crime rates from the early nineteenth to the mid-twentieth centuries and a twentieth-century "reverse J-curve" of rates that fell for the first 60 years and then rose for the ensuing 20 . Now, of course, we know that official American rates continued to rise until 1991 and have fallen continuously since.

Criminal justice history is a small field and is not well known among social scientists who study crime. The field was even smaller in the 1980s. Even so, a handful of writers-Gurr, Lane, and James Q. Wilson-tried to make sense of the $\mathrm{U}$ - and reversed J-curves. All identified 


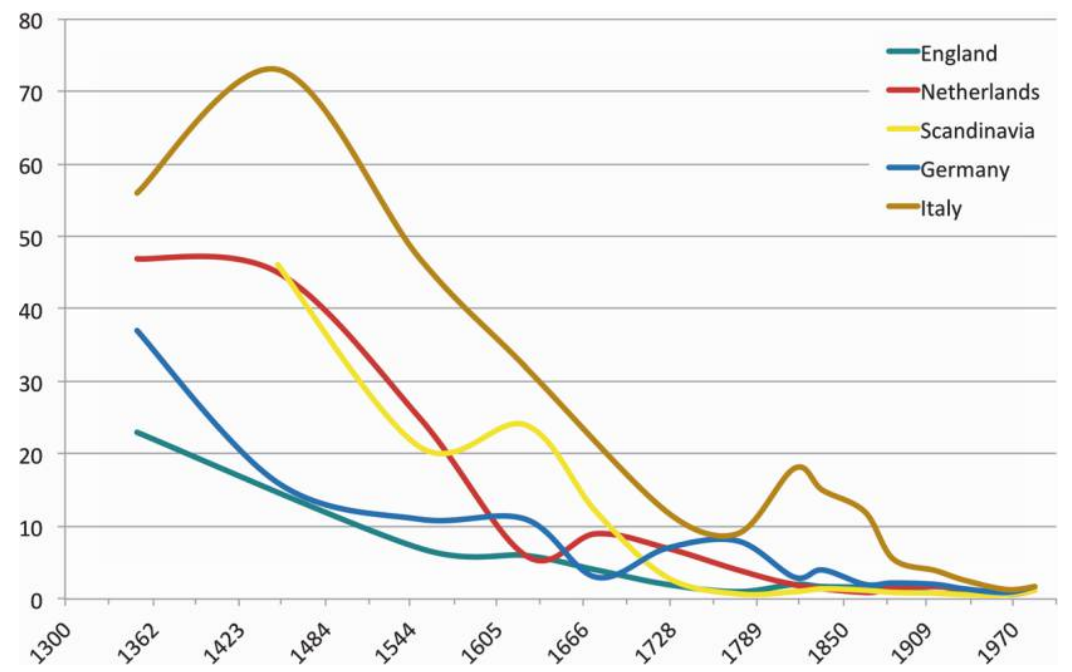

FIG. 4.-Homicide rates per 100,000 population, five European regions, 1300-2000. Source: History of Homicide Database. See Eisner $(2003,2014)$ for details on sources.

social or economic developments that, they argued, successively strengthened and then weakened individuals' capacities for self-control. In retrospect, they did pretty well, anticipating the most plausible theories offered in recent years (e.g., Fukuyama 1999; Pinker 2011; Eisner 2014).

For Gurr $(1981,1989)$ and Lane $(1989,1992)$ the fundamental explanation for the nineteenth-century decline was the development of institutions associated with modernization and the emergence of state and industrial bureaucracies. These included mandatory public education, the military, the factory, other economic institutions of the Industrial Revolution, and the expansion and bureaucratization of government. They also included the full range of modern criminal justice system institutions: professional police, juvenile training schools and later on the juvenile court, the reformatory and the prison, and parole and probation. Altogether, these institutions socialized individuals into conformity with important norms and helped create a disciplined environment characteristic of the industrializing cities of the nineteenth century. After the mid-twentieth century, buffeted by social and economic change, they lost their effectiveness.

Lane argued that the nineteenth-century changes altered people's 
capacities for self-control. They required more orderly, rational, and cooperative behavior than was necessary for independent farmers, craftsmen, and small merchants. In a preindustrial society, high levels of drunkenness, erratic or violent behavior, and unreliability affected only those immediately involved. Not so in an industrializing society, in which the work of each depended on what others did:

The state was called in then, and cops in part created to help tame a formerly unruly population-with special emphasis on drunkenness, the kind of victimless crime that private citizens did not prosecute on their own. The new public schools taught not literacy so much as discipline, as youngsters preparing for regimented lives in factory or bureaucracy learned to sit still, take turns, mind the teacher, hold their water, and listen for the bell. The literally "civilizing" institutions of the nineteenth century, from temperance societies to a variety of incarcerating institutions, worked to make the industrial cities function smoothly as far as they did because they were going with the flow, reinforcing the felt needs of the new economic order, helping to create an appropriately new kind of mass social psychology. (Lane 1992, pp. 34-35)

Lane argued that rising crime rates after the 1950s reflected the shift from an industrial to a postindustrial society; its educational and technical demands left millions behind. Good blue-collar jobs were once available to most men who would accept industrial discipline. "It was never easy," Lane wrote, "to get young people-especially young males - to go along with that discipline, and now that there is little room for those who do not take to purely academic achievement, it is nearly impossible. The result is that the schools and cops, the injunctions to stay clear of the prevailing drugs, no longer work because they are no longer serving their former economic function, and much of the population, suffering from structural un- or underemployment, no longer accepts the kind of social psychology that built the industrial city" (1992, p. 35).

James Q. Wilson (1976; Wilson and Herrnstein 1985), by contrast, paid little attention to economic and structural changes. Instead, he focused almost entirely on Protestant and Catholic religious revivals that he argued strengthened socialization into moral norms of right behavior in the nineteenth century and later lost steam and influence. The revivals, which he believed improved capacities to delay gratifi- 
cation and resist violent and other wrongful impulses, rested on a Christian foundation that held during the nineteenth and early twentieth centuries. Once personal self-control was weakened by ideas of moral relativism and norms of hedonistic self-indulgence, things fell apart: "Parents could no longer socialize their children with the authority conferred by absolute moral standards, young folks lost the ability to control their impulses, the state, in effect, lost its nerve and will to punish effectively, and the result was and has been higher crime" (summarized in Lane [1992, p. 36]).

There the matter rested for a decade. It was only after the realization began to sink in early in the twenty-first century that crime rates had peaked in the United States in 1991 and around the same time or within a few years in other Western countries that scholars began once again to look for reasons for why crime rates fall.

\section{The Recent Rise and Contemporary Fall in Crime Rates}

The recent story is better known. Figure 5 shows homicide, rape, robbery, burglary, and motor vehicle theft rates per 100,000 population in the United States from 1960 through 2012. So that trends for the five offenses can be shown in one figure, homicide and rape rates have been multiplied by 10 and burglary rates divided by 10 . With the exception of burglary, which peaked in 1981 and, despite a slight later increase, never again reached that level, the patterns for the five offenses are remarkably similar. They rise and fall, reach peaks and troughs, almost in lockstep. Rates rose from various dates in the 1960s until 1981, fell for 5 years, and except for burglary rose again until $1991 .^{3}$ Since then they have fallen more or less continuously, including in 2013.

The picture of recent declining crime rates is even more evident in

\footnotetext{
${ }^{3}$ Data from the National Crime Victimization Survey (NCVS) show broadly similar patterns (Bureau of Justice Statistics 1994). Robbery and assault victimization rates peaked in the early 1980s and again in 1991, falling afterward. Motor vehicle theft peaked in the early 1990s before beginning a long-term fall. Personal larceny, household larceny, and household burglary patterns are slightly different; all peaked in the early 1980 s and fell continuously in subsequent years. Since the NCVS was redesigned in 1992, victimization rates have declined continuously for all offenses and especially steeply for violence (Truman and Planty 2012, fig. 3; Lauritsen and Rezey 2013). Victim reporting to the police increased gradually throughout the period 1973-92 (Bureau of Justice Statistics 1994, pp. 1-5) and more sharply from 1991 to 2005 (Baumer and Lauritsen 2010).
} 


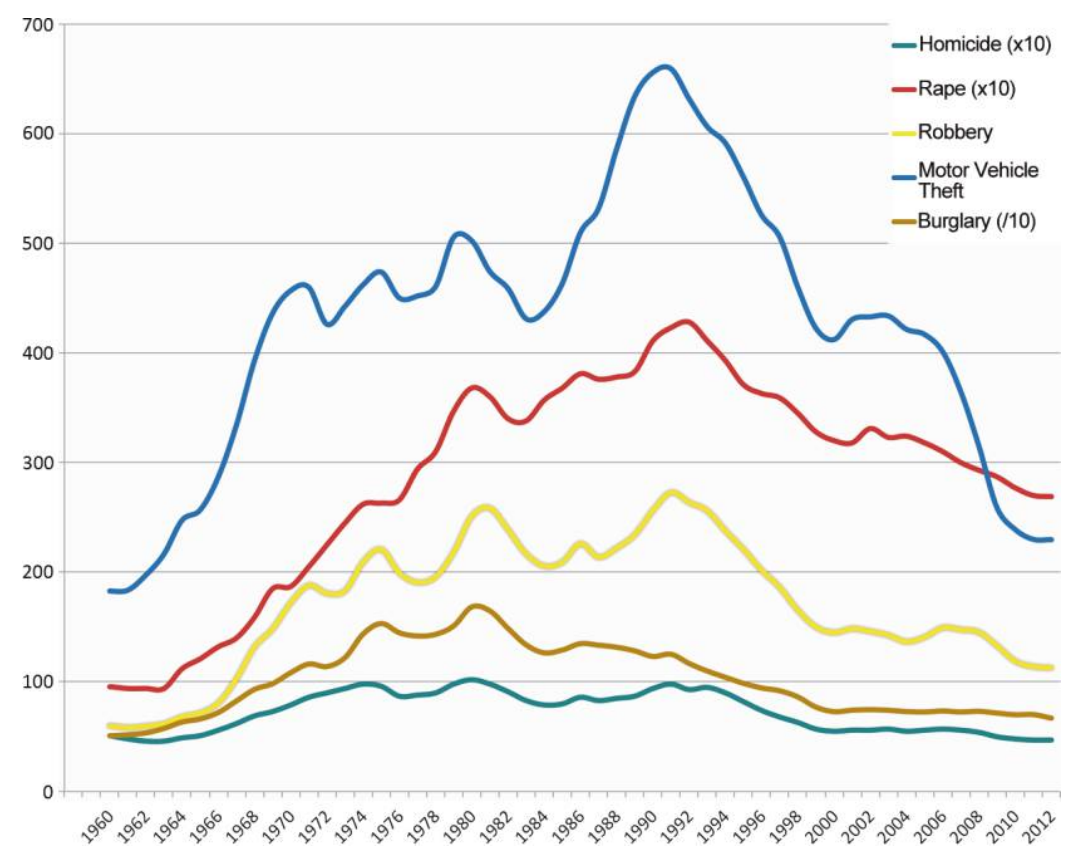

FIG. 5.-Crime rates per 100,000 population, five offenses, United States, 1960-2012. Source: Federal Bureau of Investigation, Crime in the United States, various years. To show trends for five offenses in one figure, homicide and rape rates per 100,000 population have been multiplied by 10 . Rates for burglary have been divided by 10 .

victimization data. Table 1, based on data from the 1993 and 2010 US NCVS, shows that reported victimization of individuals for most violent crimes fell by three-fourths during those years. Household victimizations for burglary, theft, and motor vehicle theft fell by two-thirds. The starting date is 1993 because that was the first year of data collection after a fundamental redesign of the survey. Victims' reports provide a broader indicator of the extent of victimization than do police data because they include both attempted and completed crimes, including many that victims did not consider serious enough to report to the police.

The rest of this section demonstrates three propositions. All aim to demonstrate that the national patterns shown by official data are accurate and that something fundamental was happening that affected all states and all developed Western countries. First, the American crime rate patterns shown in aggregate data are broadly representative of the 


\section{TABLE 1}

Victimization and Prevalence Rates, per 1,000 Persons Aged 12 or Older (Violence) or per 1,000 Households (Property), by Type of Crime, 1993 and 2010

\begin{tabular}{|c|c|c|c|c|c|}
\hline & \multicolumn{2}{|c|}{ Violence } & & \multicolumn{2}{|c|}{ Property } \\
\hline & Victimization & Prevalence & & Victimization & Prevalence \\
\hline Total: & & & Total: & & \\
\hline 1993 & 79.8 & 29.3 & 1993 & 351.8 & 171.6 \\
\hline 2010 & 19.3 & 10.8 & 2010 & 125.4 & 89.2 \\
\hline Rape/sex assault: & & & Burglary: & & \\
\hline 1993 & 7.7 & 2.6 & $1993^{\circ}$ & 63.9 & 36.2 \\
\hline 2010 & 1.9 & 1.0 & 2010 & 25.8 & 19.4 \\
\hline Robbery: & & & $\begin{array}{l}\text { Motor vehicle } \\
\text { theft: }\end{array}$ & & \\
\hline 1993 & 8.3 & 3.9 & 1993 & 19.3 & 12.1 \\
\hline 2010 & 2.2 & 1.6 & 2010 & 4.9 & 4.3 \\
\hline Aggravated assault: & & & Theft: & & \\
\hline 1993 & 16.5 & 7.6 & 1993 & 286.6 & 136.7 \\
\hline 2010 & 3.4 & 2.2 & 2010 & 94.6 & 70.1 \\
\hline Simple assault: & & & & & \\
\hline 1993 & 50.7 & 18.4 & & & \\
\hline 2010 & 12.7 & 6.9 & & & \\
\hline
\end{tabular}

SOURCE.-Lauritsen and Rezey (2013).

experiences of individual American states and major cities. Second, American patterns of declining homicide and property crime rates characterize all western European and developed English-speaking countries. Third, patterns of nonlethal violent crime since the early 1990s appear-albeit misleadingly—to vary substantially between countries. In the English-speaking and some western European countries, rates for nonlethal violence have fallen substantially, paralleling homicide and property crime. In other western European countries, rates of nonlethal violent crime have either increased substantially or in any event not fallen (Aebi and Linde 2010, 2012; Selmini and McElrath 2014). In some countries, including those in Scandinavia, both police and victimization survey data show increases in rates of nonlethal violence. Kivivuori (2014) shows, however, that those figures should not be taken at face value.

\section{A. American Crime Trends in States and Cities}

The robustness of American crime rate declines can be seen by looking at patterns in states and cities. In this subsection, I present and briefly discuss homicide and robbery trends in the five largest states by population and homicide trends in the 10 largest cities. Because the 
United States includes 50 states, the District of Columbia, Puerto Rico, and several smaller territories, "national averages" can be materially misleading. In the case of crime trends, they are not.

The problem can be illustrated by thinking about imprisonment rates. The overall state and federal imprisonment rate at year-end 2012, for example, was 480 per 100,000 population. The national rate, however, is afflicted by the sad tale of the statistician who drowned in a lake that was, on average, 3 inches deep. Means can mislead. There are huge differences in imprisonment rates between states. Maine's state imprisonment rate in 2012 was 145 per 100,000 . When local jail inmates are taken into account, the total is about 200 per 100,000 . That is well above the western European average but only slightly higher than the rates in England, New Zealand, and Spain and lower than those in much of eastern and central Europe. The highest rates, Louisiana's, were 893 per 100,000 when only state prisoners are counted and over 1,300 including jail inmates. Louisiana has by far the world's highest imprisonment rate, more than double those of Russia, Ukraine, and Belarus. Louisiana's rate in 2012 was also nearly double the total US rate, including jail inmates, of 717 per 100,000 (Carson and Golinelli 2013, table 8; Minton and Golinelli 2014, table 1). Imprisonment rates in all American states increased substantially after 1973, but the degree of increase and absolute rates varied enormously (Travis and Western 2014, chap. 2).

For comparison of crime trends, the relevant measure is not absolute rates but patterns of change. The patterns have been consistent throughout the United States. Figures 6 and 7 show changes in homicide and robbery rates for the five most populous states since 1980 . More than a third of Americans live in them. Rates are standardized at one in 1980. Both figures follow the national patterns. Rates peaked in 1981-82, followed by a drop through the mid-1980s and a late 1980s climb to a higher peak in the early 1990s. After that the declines were continuous. In the most recent years, homicide rates were 40-60 percent lower than the starting point and a third to half their peaks. Robbery rates fell to levels $10-60$ percent below the starting points and vastly below the intermediate peaks. The robbery data understate the declines. Homicide is the most reliably measured crime both because the indicator is unambiguous and because trends in police data can be validated with health statistics data on deaths from intentional injury. Robbery data are much more likely to be affected by changes in victim 


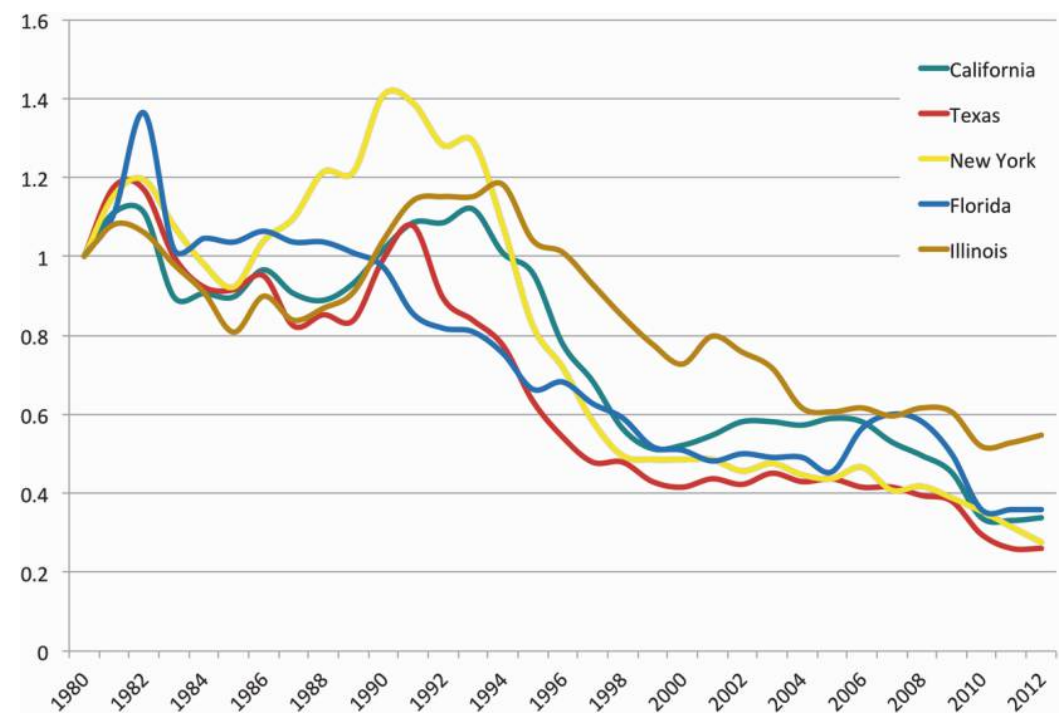

FIG. 6.-Standardized homicide rates per 100,000 population, five most populous American states, 1980-2012. Source: Federal Bureau of Investigation, Crime in the United States, various years. Rates have been standardized using state homicide rates in 1980 as bases valued as one. The figure shows trends in each state relative to its starting point.

reporting and police recording. They are also more likely to be affected by changes in criminal opportunities such as the increased prevalence of ownership of mobile telephones and other small electronic devices.

Figure 8 shows trends in homicide for the 10 most populous cities. Rates are standardized at one in 1990. Most cities experienced small increases in the early 1990s, followed by continuous falls through 2000. One clear implication is that "zero-tolerance" and "public order" policing in New York City played at most a small role in reducing homicide rates. During that decade of steep decline, rates in San Diego and Houston plummeted as precipitously. In the most recent years, every city's rate is at least 25 percent below the starting point, most are 60 percent below, and New York City's is 80 percent below. New York's anomalous 2001 rate results from the World Trade Center deaths.

\section{B. Cross-National Measures of Victimization and Offending}

Quantitative cross-national efforts to compare crime patterns pose formidable methodological challenges, some of which are discussed in 


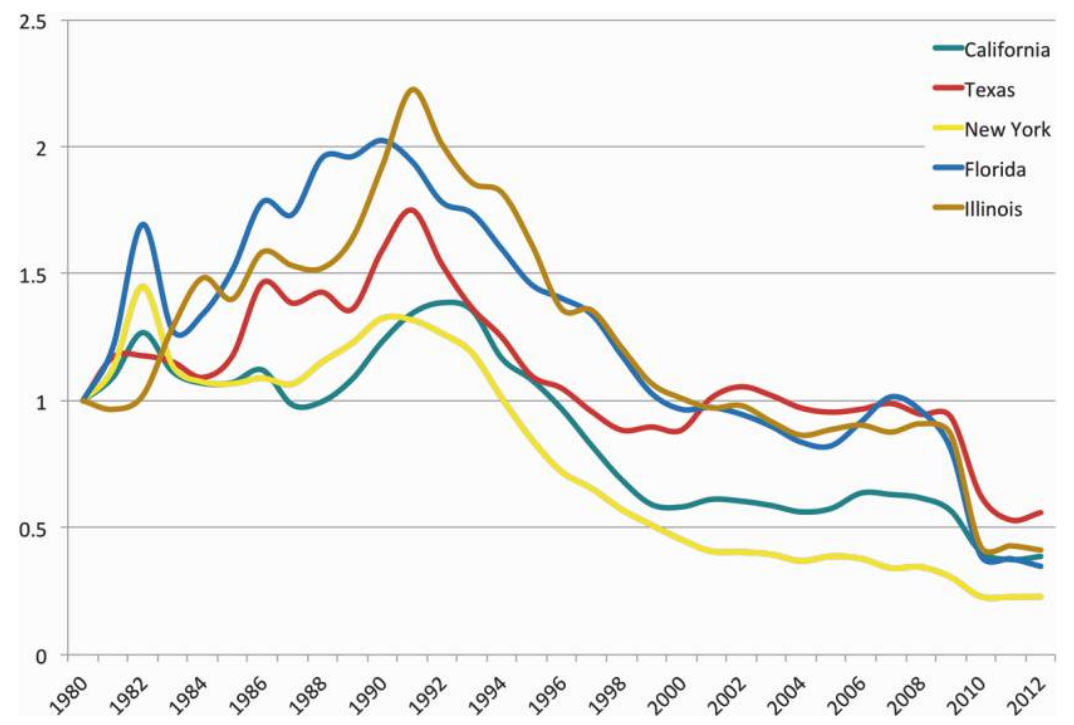

FIG. 7.-Standardized robbery rates per 100,000 population, five most populous American states, 1980-2012. Source: Federal Bureau of Investigation, Crime in the United States, various years. Rates have been standardized using state robbery rates in 1980 as bases valued as one. The figure shows trends in each state relative to its starting point.

following subsections. Efforts are being made to establish reasonably reliable cross-national data systems. These include the UN Surveys on Crime Trends and the Operations of Criminal Justice Systems (Harrendorf, Heiskanen, and Malby 2010), the European Sourcebook of Crime and Criminal fustice Statistics (Aebi et al. 2010), and the International Crime Victims Survey (ICVS; van Dijk, van Kesteren, and Smit 2007). ${ }^{4}$ The first two remain relatively primitive because of basic cross-national differences in how crimes are defined and recorded (Alvazzi del Frate 2010 [UN data]; Harrendorf 2012 [European Sourcebook]).

The ICVS has been administered five times beginning in 1989 in a wide range of countries and cities. The core elements of the survey instrument are standardized though translated into appropriate languages. Questions ask about victimization experiences in everyday language and neither use nor assume knowledge of statutory offense def-

${ }^{4}$ The most successful such cross-national effort, though covering only the Scandinavian countries, is Nordic Criminal Statistics, 1950-2010 (von Hofer, Lappi-Seppälä, and Westfelt 2012). 


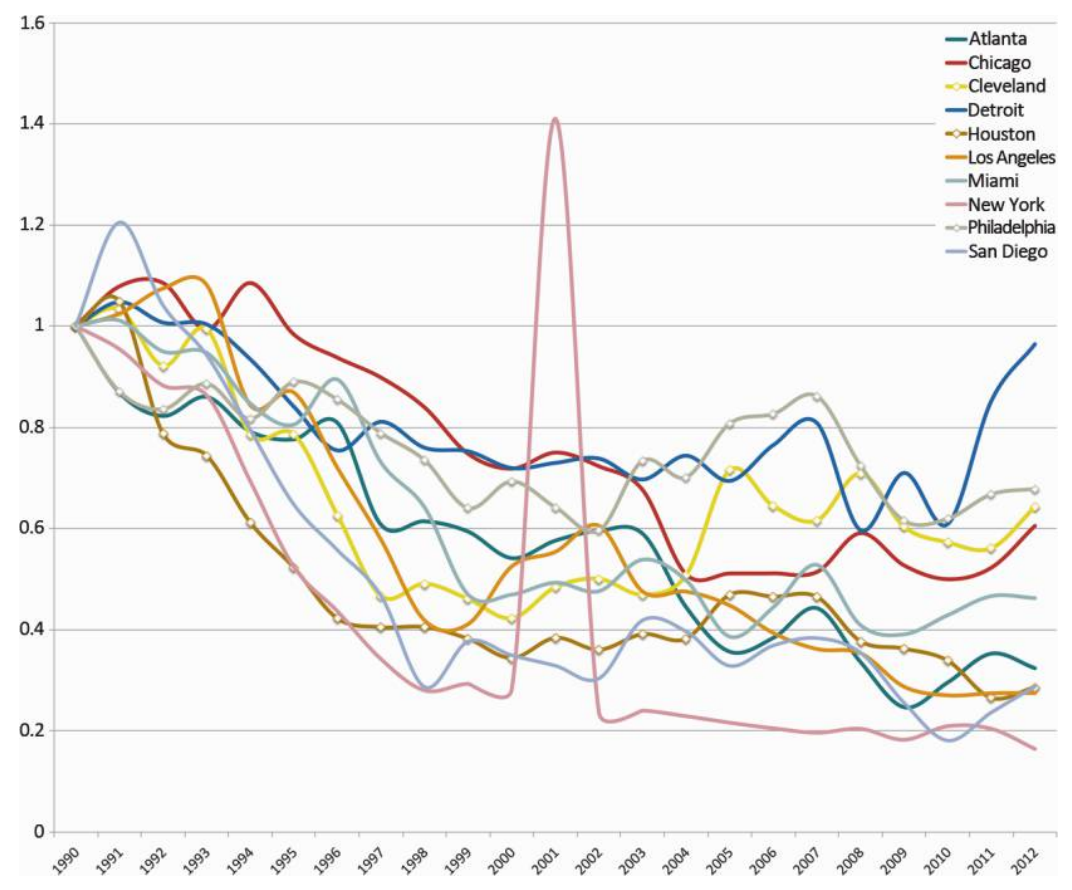

FIG. 8.-Standardized homicide rates per 100,000 population, 10 most populous American cities, 1990-2012. Source: Federal Bureau of Investigation, Crime in the United States, various years. Rates have been standardized using homicide rates in 1990 as bases valued as one. The figure shows trends in each state relative to its starting point.

initions. Surveys use representative national samples that average 2,000 subjects. Participation rates have varied over the years, typically ranging between 50 and 70 percent. Administering the surveys and analyzing the data of course pose significant methodological and statistical challenges. Nonetheless, the findings for developed Western countries are highly consistent and confirm the belief that crime rates have generally been falling since the early and mid-1990s.

Figures 9, 10, and 11 show the percentages of respondents reporting victimizations in seven English-speaking and European countries that participated in four or five ICVS waves. The green and white striped lines show averages for all countries (not only the seven shown). Figure 9 shows percentages reporting any crime victimization. Figures 10 and 11 show data for one violent offense (assault) and one property offense (burglary). Figures A1 and A2 in the appendix show results for the 


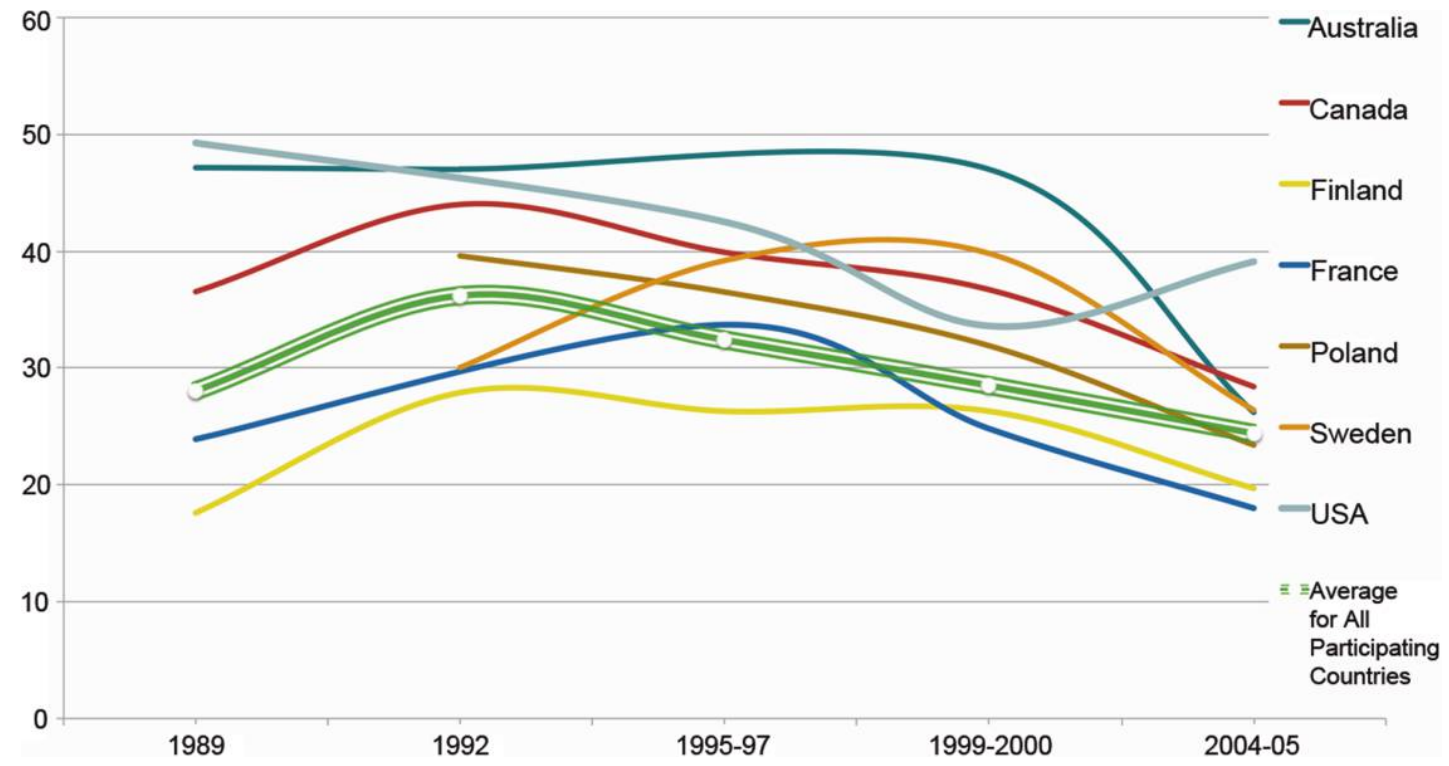

FIG. 9.-Percentages of respondents reporting any victimization, ICVS, four or five waves, seven and all participating countries. Source: van Dijk et al. (2007, table 5). 


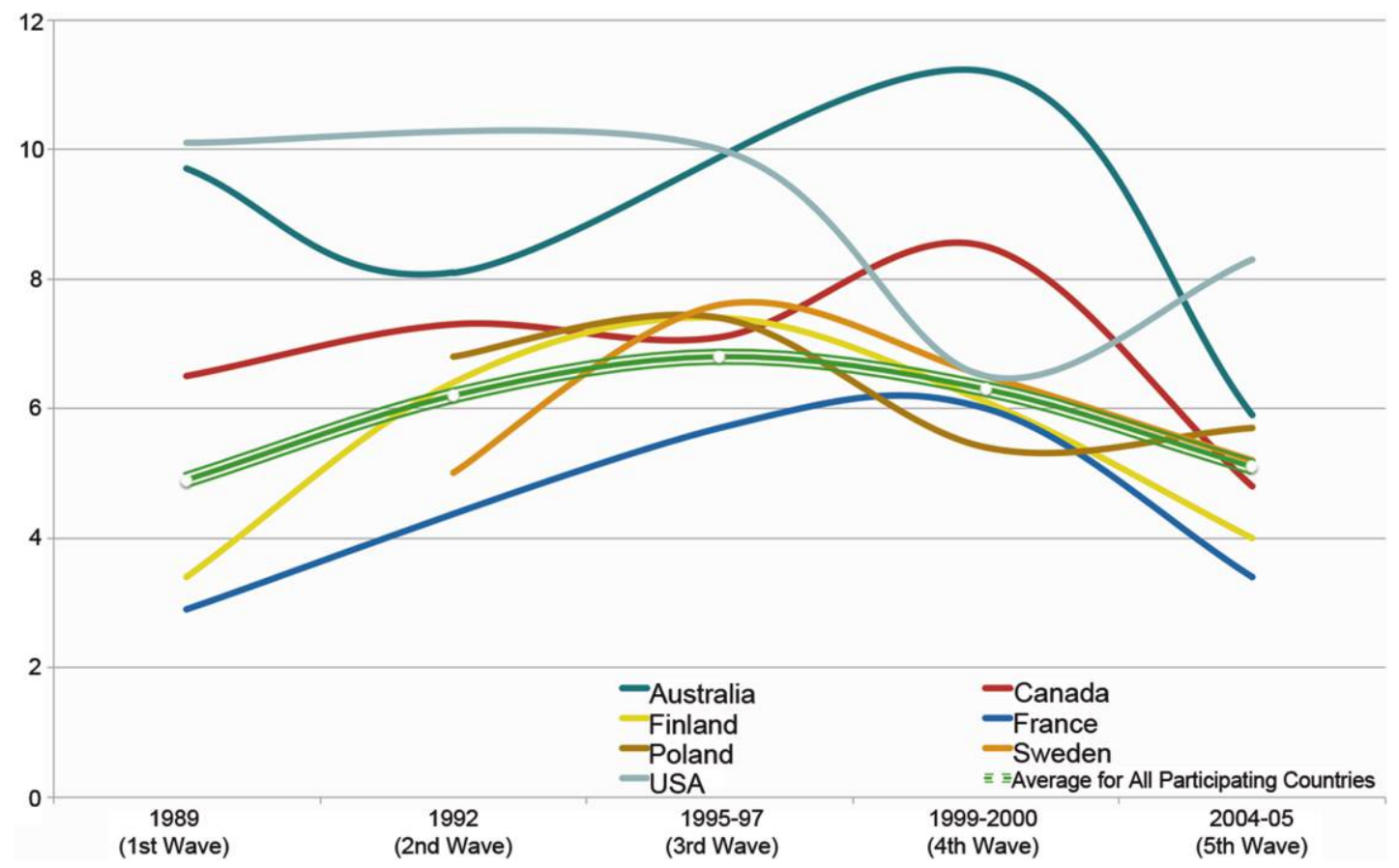

FIG. 10.-Percentages of respondents reporting assaults, ICVS, four or five waves, seven and all participating countries. Source: van Dijk et al. (2007, table 5) 


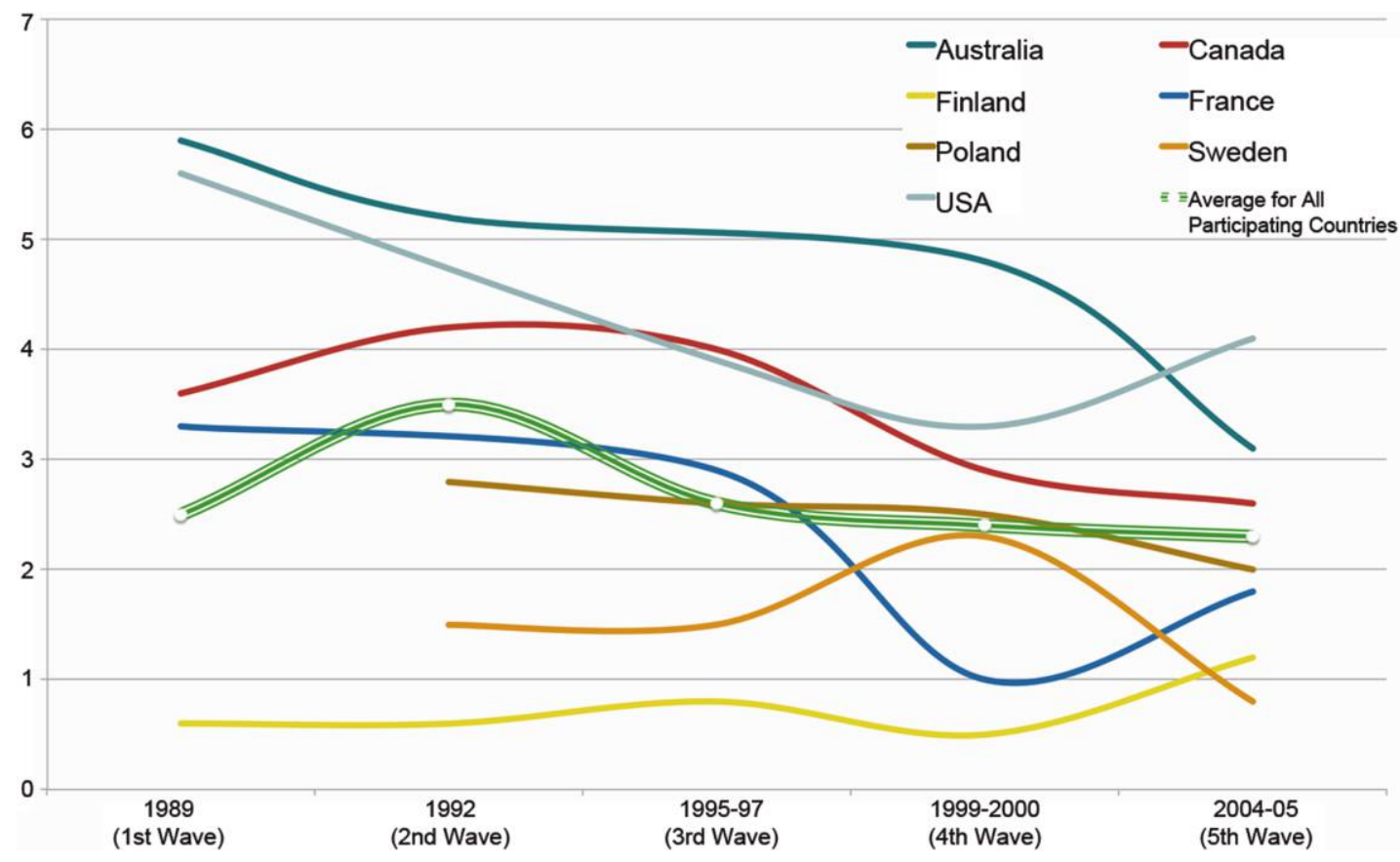

FIG. 11.-Percentages of respondents reporting burglaries, ICVS, four or five waves, seven and all participating countries. Source: van Dijk et al. (2007, table 5) 
other two most commonly reported victimizations - auto theft and personal theft.

All the ICVS figures show the same thing, despite fluctuations attributable to the small sample sizes and-in some countries in some years-low participation rates: victimization rates rose in most countries after the 1989 wave of data collection, peaked in the early and mid-1990s, and have fallen since. This closely follows the patterns shown in American victimization (see table 1; Truman and Planty 2012, fig. 3) and police data (see fig. 5).

To round out this survey of broadly cross-national data, figure 12 shows data from the British Crime Survey from 1981 to 2010 for all property and violent offenses, for serious assaults (involving injuries), and for the three most common property crimes. England is the only country outside Scandinavia and the United States that has long conducted annual victimization surveys using large representative national samples. The patterns for all offenses are the same: rises in the 1980s, peaks in the early 1990s, and subsequent substantial continuing declines.

Take altogether, the American, English, and ICVS data lay a foundation for at least a tentative hypothesis that crime rates in recent decades have followed much the same patterns in Western countries for all crimes and separately for violent and property offenses.

\section{Homicide and Property Crime Trends in Western Countries}

There is now general agreement, at least for developed Englishspeaking countries and western Europe, that homicide patterns have moved in parallel since the 1950s (Eisner 2008). The precise timing of the declines has varied, but the common pattern is apparent. Homicide rates increased substantially from various dates in the 1960s, peaked in the early 1990s or slightly later, and have since fallen substantially. Property crime rates have declined everywhere since at least the early 1990s (Aebi and Linde 2010, 2012). I provide illustrative data for the English-speaking and Scandinavian countries because they, as groups of countries, provide polar cases.

1. Homicide. Figures 13 and 14 show Scandinavian and Englishspeaking country homicide rates, standardized at one on the 1960 rates. ${ }^{5}$ There are no clear patterns in Scandinavia until the early 1970s,

\footnotetext{
${ }^{5}$ Except for Australia, for which reasonably reliable national data are available only from 1993 (Carcach 2005).
} 


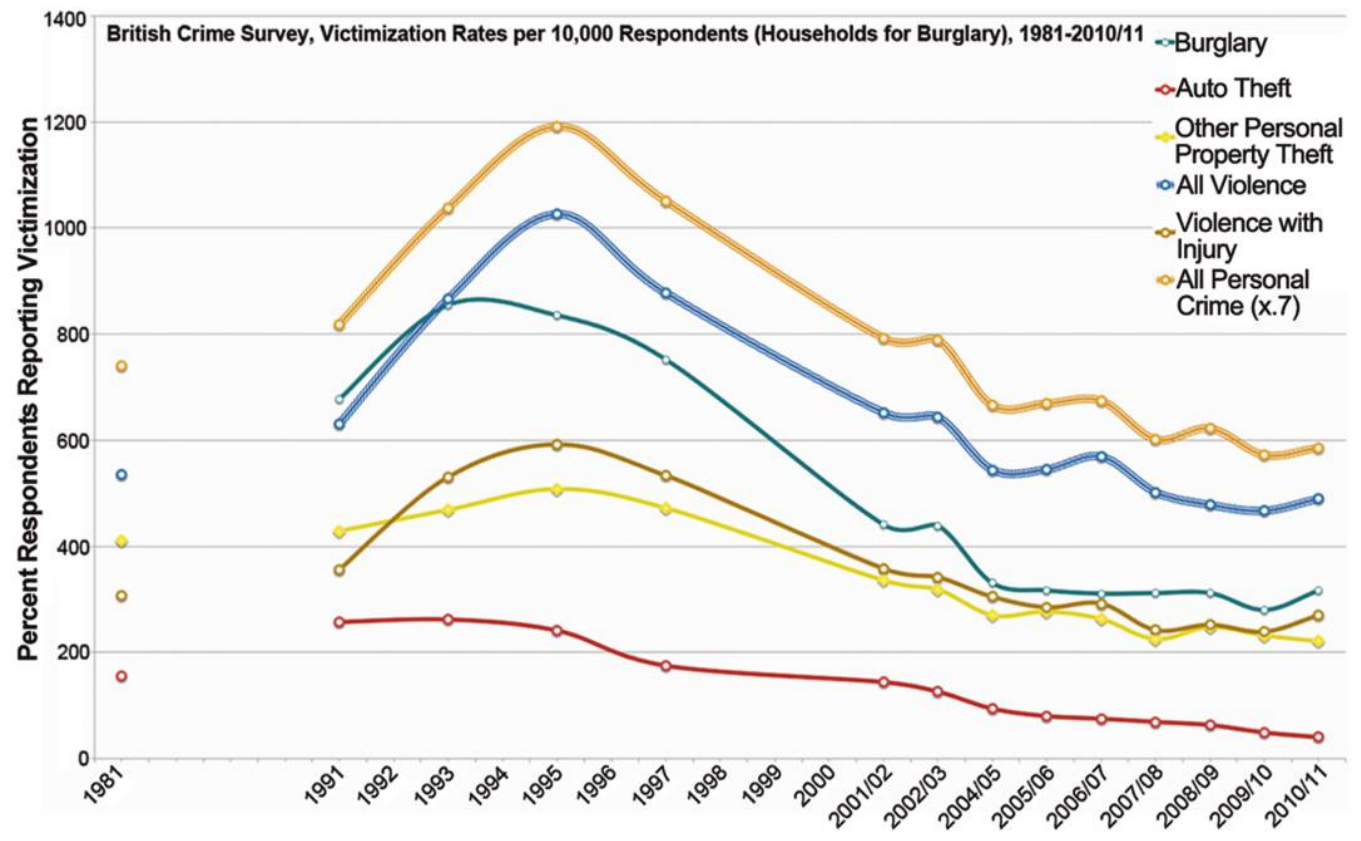

FIG. 12.-Victimization rates per 10,000 respondents aged 16 or over, or per 10,000 households, British Crime Survey, selected offenses, 1981-2010/11. Source: Chaplin et al. (2011, table 2.02). 


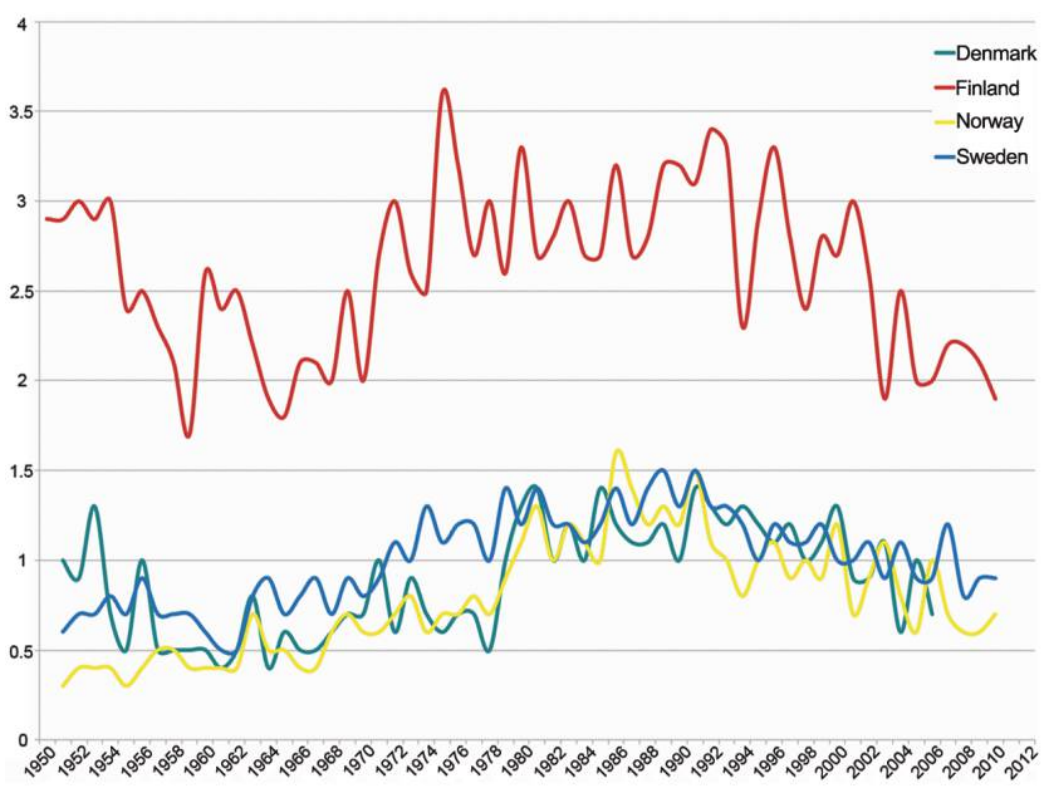

FIG. 13.-Homicide rates per 100,000 population, four Scandinavian countries, 1950-2012. Sources: 1950-2010: von Hofer et al. (2012, table 1); 2011-12: data provided by Tapio LappiSeppälä.

when rates began to rise in all four countries (least in Finland), peaking in the early 1990s, and dropping substantially since. Except in Finland, whose traditionally higher homicide rate ranged between 1.9 and 3.4 per 100,000 population, rates in the other Scandinavian countries fluctuate around one per 100,000. In recent decades they have usually been lower (von Hofer 2011; von Hofer and Lappi-Seppälä 2014). In countries of 4-8 million people, small differences in absolute numbers cause noticeable year-to-year rate fluctuations.

English-speaking patterns are similar, albeit with a lagged decline in England and Wales. Rates in Canada and the United States rose rapidly beginning in the mid-1960s, peaking around 1980, fluctuating at high levels during the 1980s, and peaking again in the early 1990s. After that, they fell sharply, as did Australia's after 1993. The pattern in England and Wales is similar except that the peak is a decade later. The English pattern is substantially affected by the case of Dr. Harold Shipman, who was convicted of killing 15 of his patients but was later established to have killed at least 215 , with authoritative estimates that 


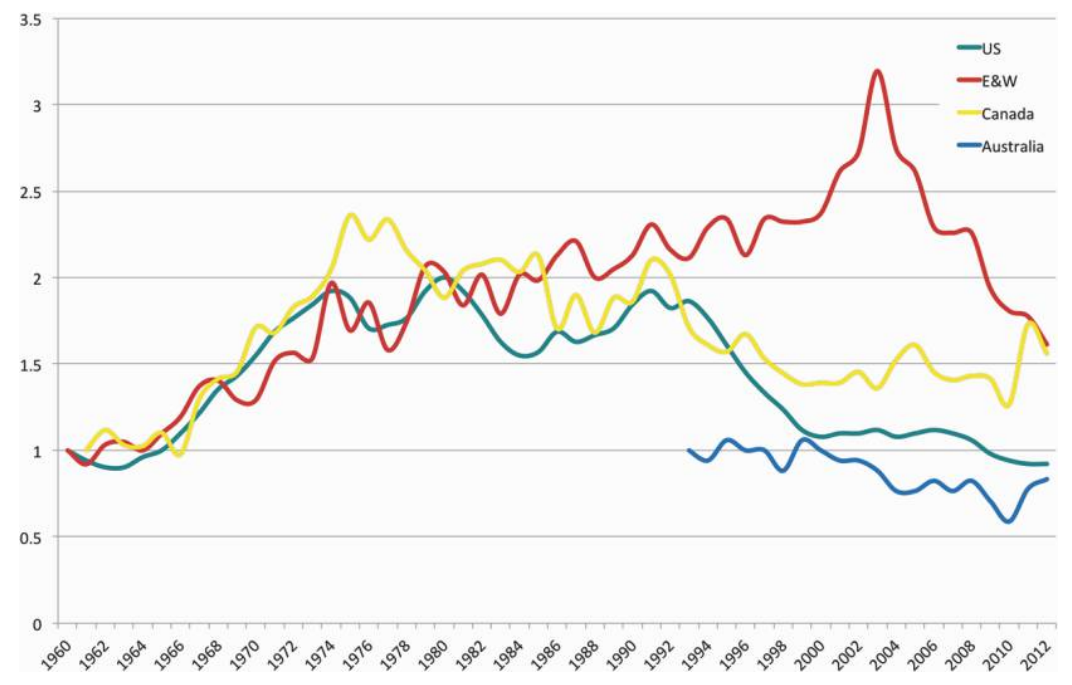

FIG. 14.-Standardized homicide rates per 100,000 population, four English-speaking countries, various years to 2012. Sources: Australia: Australian Bureau of Statistics; Canada: Statistics Canada; England and Wales: Office for National Statistics; United States: Federal Bureau of Investigation, Crime in the United States, various years. Rates have been standardized using homicide rates in 1960 in England and Wales and the United States, 1961 in Canada, and 1993 in Australia as bases valued as one. The figure shows trends in each country relative to its starting point.

altogether there may have been more than 260 (Smith 2003). England's homicide rate has fluctuated around one per 100,000 for the past 50 years. As in Scandinavia, comparatively small year-to-year differences in absolute numbers cause significant fluctuations in rates. ${ }^{6}$ It is important to recall that figure 14 shows standardized data. American rates are typically four to eight times higher than those in England and Wales, three to four times those in Canada, and five to six times those in Australia. ${ }^{7}$

2. Property Crime. There is wide agreement that property crimes

${ }^{6}$ From 1990 to 1999 , the annual number of homicides ranged between 669 and 750 (see table 2 below). After anomalous high absolute numbers in 2001 and 2002, the rate returned to the prior range and then declined, reaching 553 in 2011 and 552 in 2012 (Office of National Statistics 2013, table 6a).

${ }^{7}$ In 1993, e.g., the first year for which Australian data are shown, the American rate was 9.5 per 100,000, the English 1.31, the Canadian 2.19, and the Australian 1.7. In 2010, the American rate was 4.8, the English 1.12, the Canadian 1.62, and the Australian 1.0 . 
are declining in all developed countries, so I do not belabor the point (van Dijk, Tseloni, and Farrell 2012a). Figures 15 and 16 show trends for the United States, England and Wales, and the Scandinavian countries. First, however, a few words about cross-national comparison of official data are called for.

Countries vary substantially in police recording practices. Even homicide data can be suspect: validation against intentional homicide data in health statistics shows significant differences even in some developed countries and huge differences in many less developed countries (Smit, de Jong, and Bijleveld 2012; Lappi-Seppälä and Lehti 2014). Problems of data comparability are much greater, however, for other offenses (Aebi 2010; Harrendorf 2012). English-speaking common-law countries share roughly comparable legal definitions for offenses such as robbery, burglary, theft, and motor vehicle theft. So do the Scandinavians. The picture is vastly more complex in the rest of continental Europe. In some countries, burglary is a subset of theft and sometimes includes takings from houses, other buildings, and cars. "Motor vehicle theft" sometimes includes motorcycles, which in some countries are much more prevalent than in the English-speaking countries. "Robbery" is often not a separate category at all; offenses Americans would think of as robberies are distributed across a number of separate offense categories. And so on. Analyses of, for example, police data on motor vehicle thefts or burglaries in the United States and European countries are often apples-and-oranges comparisons and are bound to be misleading unless very careful adjustments are made (Tonry and Farrington 2005). ${ }^{8}$ That is why I use English-speaking and Scandinavian countries to offer comparisons. Within each set of countries, offense definitions are broadly comparable.

Even within those sets of countries, figures showing comparative trend data cannot validly be used as a basis for drawing comparative

\footnotetext{
${ }^{8}$ This is the Achilles' heel of the admirable European Sourcebook of Crime and Criminal fustice Statistics (Aebi et al. 2010). The police data, compiled according to national offense definitions, are adjusted to make them comparable to standardized generic definitions and "checked" by national correspondents for each country: "Each correspondent would be an expert in crime and criminal justice statistics and would act as a helpline. They would also be entrusted with checking their country's data to ensure good quality. . . . They had full responsibility for the accuracy of the data provided by their respective countries" (p. 16). This means that the reliability of the "comparable" data eventually published depends critically on individuals in each country who must make adjustments to the official data and inevitably vary in their knowledge, sophistication, conscientiousness, and idiosyncrasies (Harrendorf 2012).
} 


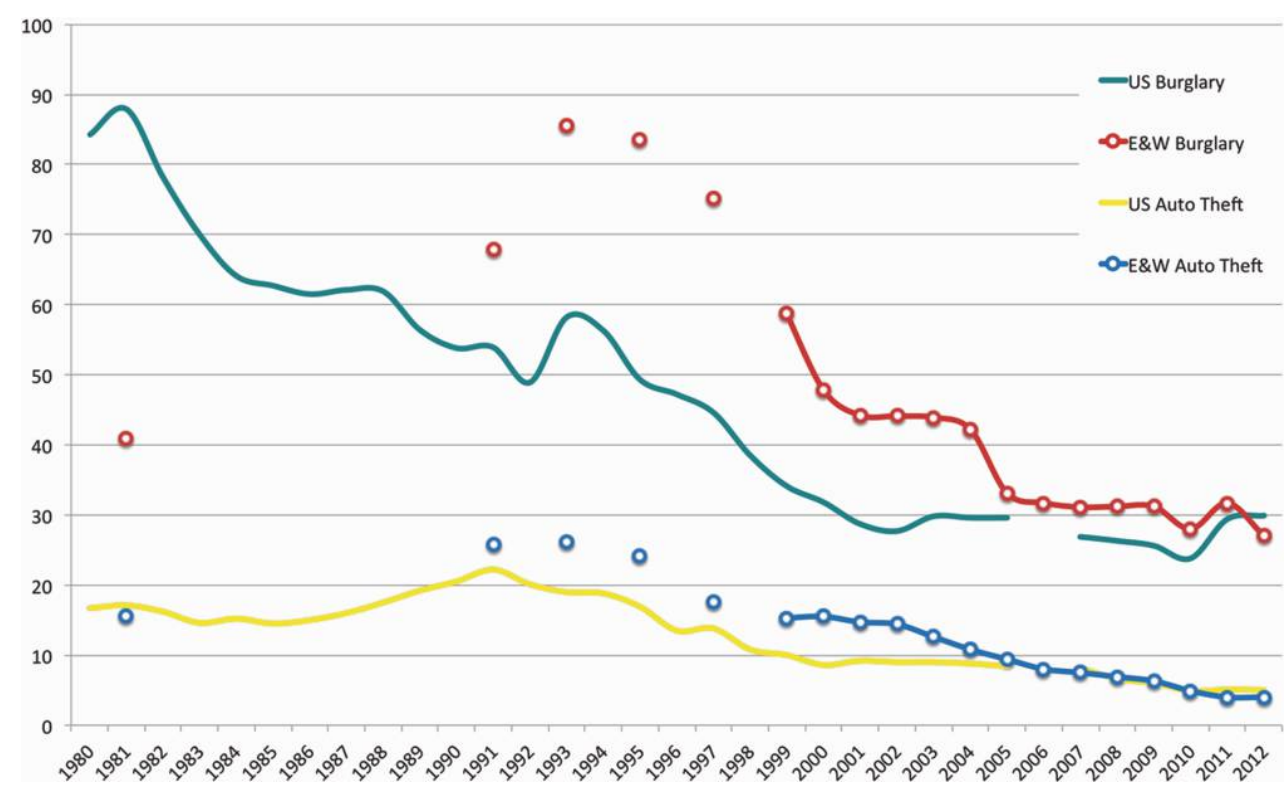

FIG. 15.-Victimization survey respondents reporting burglary or automobile theft, England and Wales, since 1981 and household burglary or motor vehicle theft, United States, since 1980. Sources: England and Wales: Chaplin et al. (2011, table 2.03); Office of National Statistics (2013, table 1.06); Bureau of Justice Statistics, NCVS. Rates in both countries are per 1,000 households. 


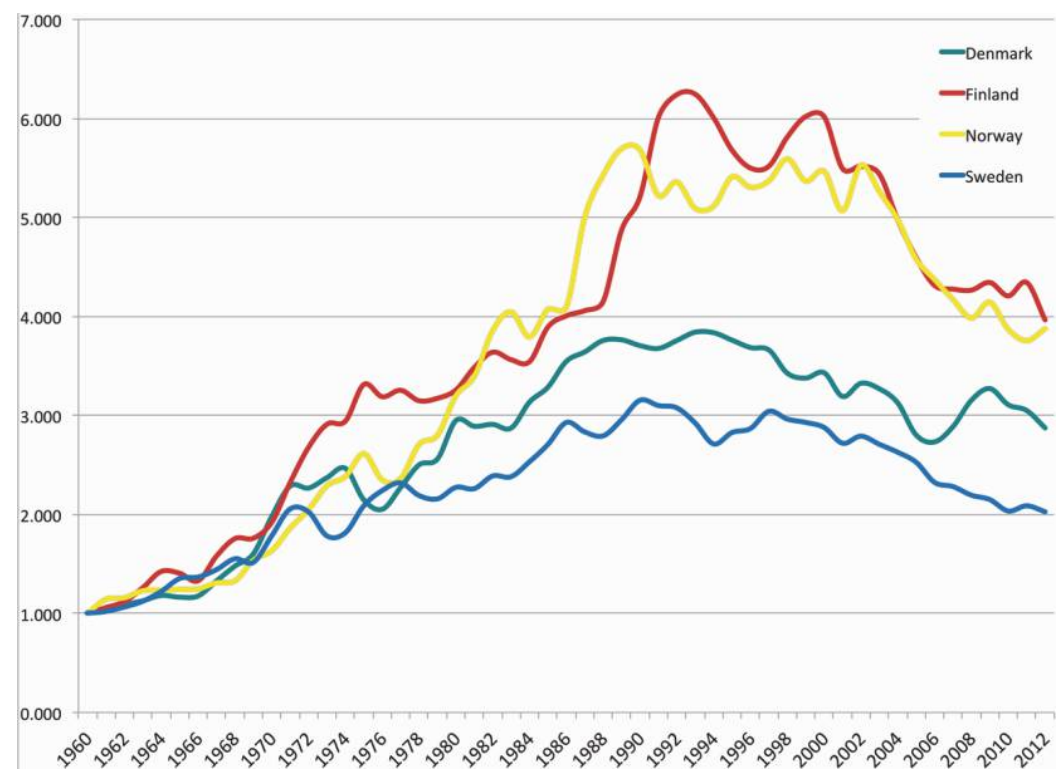

FIG. 16.-Thefts per 100,000 population, four Scandinavian countries, 1950-2012. Sources: 1950-2010: von Hofer et al. (2012, table 5); 2011-12: data provided by Tapio Lappi-Seppälä. Rates have been standardized using theft rates in 1960 as bases valued as one. The figure shows trends in each country relative to its starting point.

conclusions about crime levels. They can be used with greater confidence to compare trends. Crime-level comparisons cannot be made because recording practices vary. Minor thefts in some countries, for example, are commonly recorded in police data and in others they are not. The same differences exist for assaults.

Countries vary in how carefully they screen reported incidents before deciding whether to record them as crimes. Some operate "output" systems. This means that offenses are recorded only when police decide that the offense occurred and meets legal definitions. Others use "input" systems. This means that offenses are recorded as they are reported, without screening. Not surprisingly, input countries have higher crime levels than output countries (e.g., Aebi 2008, 2010; Harrendorf 2012).

Thus, even among sets of countries that use similar offense definitions, analyses of comparative trend data need to be sensitive to changes in recording policies. England and Wales, for example, made 
major crime-recording shifts in 1998-99 and 2002-3: to record many more minor offenses (Povey and Prime 1999) and to shift from an output to an input system (Simmons and Dodd 2003; Hough et al. 2005). The Home Office estimated that the 2002 change increased total crime rates by 10 percent in $2002 / 3$ and that the effects were especially significant for violent crimes (Simmons and Dodd 2003).

Figure 5 showed American motor vehicle theft and burglary trends in official data since 1960 with rises during the 1960s through the 1980s and steep declines since. Figure 15 shows the same pattern in victimization data in recent decades for those two offenses in the United States and England and Wales. I have used victimization data so as to avoid the effects of the recent English changes in police recording practices. In the United States, burglary victimization rates declined continuously after 1981 and motor vehicle theft rates after 1991. Rates for both offenses declined continuously in England and Wales beginning in the early 1990s.

Figure 16 shows similar theft trends in official Scandinavian data since 1960 standardized to the 1960 rates. Theft and fraud are the only nonviolent property offenses for which time-series data are readily available (von Hofer et al. 2012). Rates rose continuously in all four countries to a peak in the early 1990s and have since fallen substantially.

3. Nonlethal Violent Crime. This is where things become more complicated. To this point, there is convincing evidence of steady, substantial declines in lethal violence in Western countries from the late Middle Ages to the nineteenth century, a continuing decline in rates for many offenses in selected countries through the mid-1950s, and rising rates for all major offenses in all developed Western countries through the early 1990s. Since then, there is convincing evidence of declines in homicide and the major property crimes in all developed Western countries (Baumer and Wolff 2014; Farrell et al. 2014; LappiSeppälä and Lehti 2014). Concerning nonlethal violence the evidence is mixed. In the English-speaking countries and some continental European countries, nonlethal violence as shown in official data is declining (Aebi and Linde 2010, 2012). Official data in other continental European countries, sometimes backed up by victimization data, show increases (see, e.g., Kivivuori 2014; Selmini and McElray 2014).

Figures 17-20 tell the tale. First the English-speaking countries. Figure 17 shows robbery rates per 100,000 population in official data from 


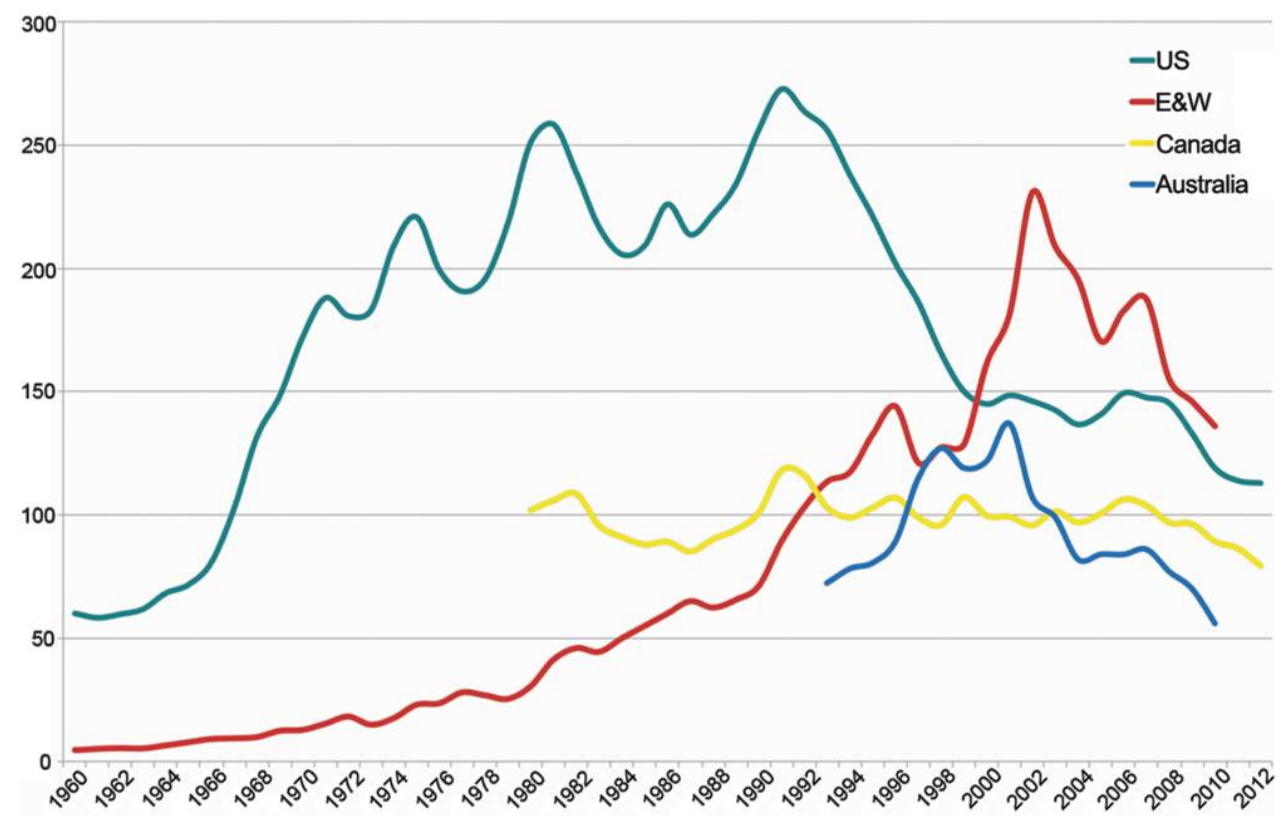

FIG. 17.-Robbery rates per 100,000 population, four English-speaking countries, various years to 2012. Sources: Australia: Australian Bureau of Statistics; Canada: Statistics Canada; England and Wales: Office for National Statistics; United States: Federal Bureau of Investigation, Crime in the United States, various years. 


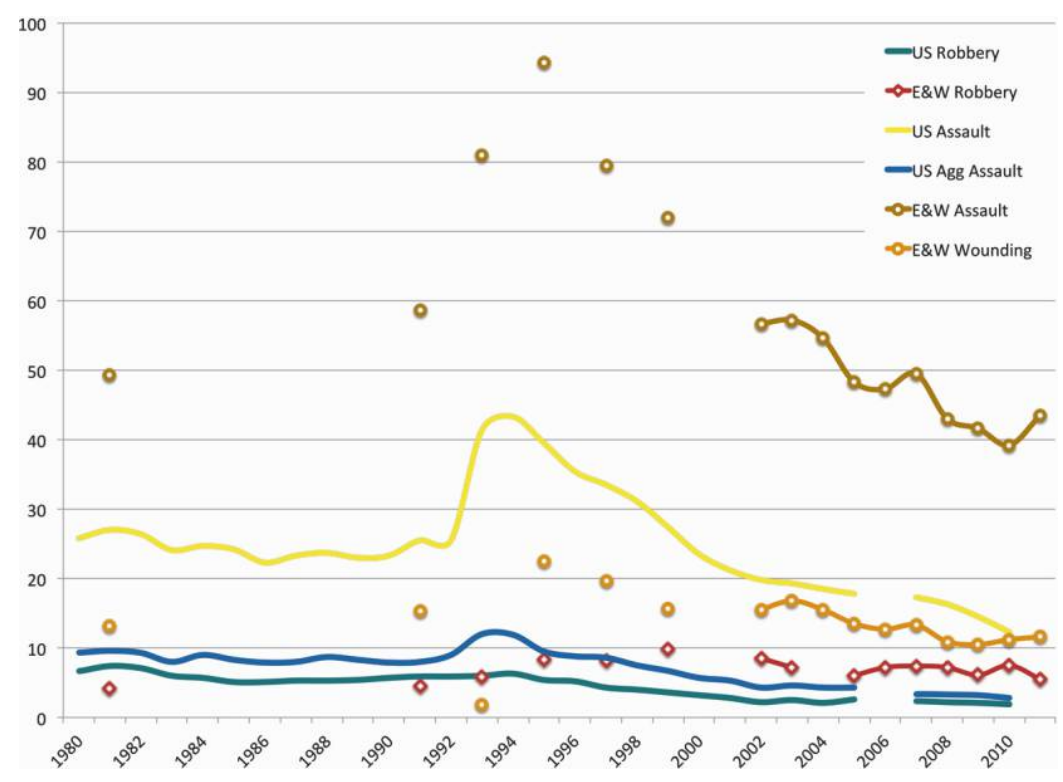

FIG. 18.- Respondents per 1,000 reporting victimization by robbery, assault, or aggravated assault, England and Wales since 1981 and United States since 1980. Sources: England and Wales: Chaplin et al. (2011, table 2.02); United States: Bureau of Justice Statistics, Criminal Victimization, various years; Sourcebook of Criminal fustice Statistics Online (http://www.albany.edu/ sourcebook/pdf/t322010.pdf, table 3.2.2010). Victimization rates for England and Wales are per 1,000 population aged 16 and older. Victimization rates for the United States are per 1,000 population aged 12 and older.

1960 to the most recent dates for which data are available. Continuous time series are available for England and Wales and the United States. Data are shown for Canada and Australia from the years when reasonably reliable national data became available (Carcach 2005; Welsh and Irving 2005). The data for the United States and Canada show sharp rises through 1991 and significant drops since. The data for England and Wales show a continuous rise through 1996, followed by a drop and a subsequent steep rise that is no doubt attributable to the 1998 and 2002-3 changes in counting rules discussed above. After 2002, the English rates quickly fell by 50 percent. The Australian data show rises through the early 2000s, followed by a precipitate 60 percent drop.

Figure 18 shows victimization data for robbery, aggravated assault, and all assaults per 1,000 residents aged 16 and up for recent years in England and Wales and aged 12 and up in the United States. I use 
victimization data because they are not distorted by changes in English counting rules. Here the picture is much clearer than in the official data. In the United States, the trends for all three offenses parallel the trends shown in official data. The victimization data for England and Wales closely track the American pattern, with steady drops since the early 1990s.

As a whole, the data from the English-speaking countries tell a consistent story: violence rates rose substantially until the early and mid1990s and dropped substantially afterward. Despite the complexities in the English data, all four countries show substantial declines in nonlethal violence in the 2000s.

The Scandinavian story is otherwise. Figure 19 shows robbery rates, standardized as one on the 1960 rate, from 1960 to 2010. Through the early 1990s, they parallel the English and American patterns, with steep rises through the early 1990s, followed by steep declines through the mid-1990s. After that, however, except arguably for Finland, the pattern is entirely different. Rates rise again in the late 1990s to peaks for three of the countries in 2000 and, except for Finland, where rates decline, fluctuate at the new higher level.

The Scandinavian difference is even more acute for assault, as the standardized data in figure 20 show. $^{9}$ Except for periods of decline in the 1990s in Finland and Denmark, the overall pattern is of continuous increases for 50 years, with the possibility of a change of direction in the early 2000s. That is too soon to tell.

So there it is. On the face of official data trends, the Scandinavians have experienced long-term and recent patterns in homicide and property crime that parallel those in the English-speaking countries. The same official data, however, show radically different trends in nonlethal violence since 1990. Either there are different stories to be told about crime trends in the English-speaking countries and Scandinavia (and other continental European countries) or there is one story but it is obscured by changes in reporting, recording, and changing cultural thresholds of tolerance. There is only one story: crime rates are falling throughout the developed Western world.

9 The Scandinavian difference is especially marked concerning sexual offenses in official data (Selmini and McElray 2014). 


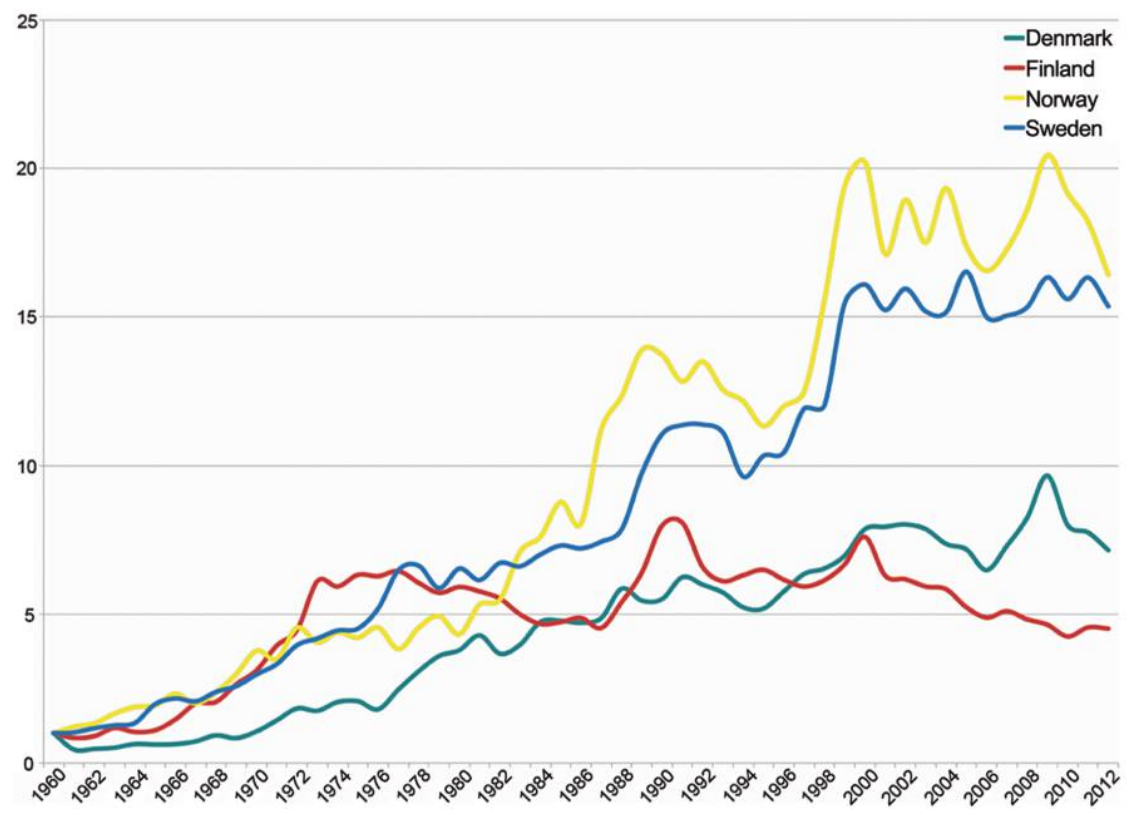

FIG. 19.-Standardized robbery rates per 100,000 population, four Scandinavian countries, 1950-2012. Sources: 1950-2010: von Hofer et al. (2012, table 4); 2011-12: data provided by Tapio Lappi-Seppälä. Rates have been standardized using robbery rates in 1960 as bases valued as one. The figure shows trends in each country relative to its starting point. 


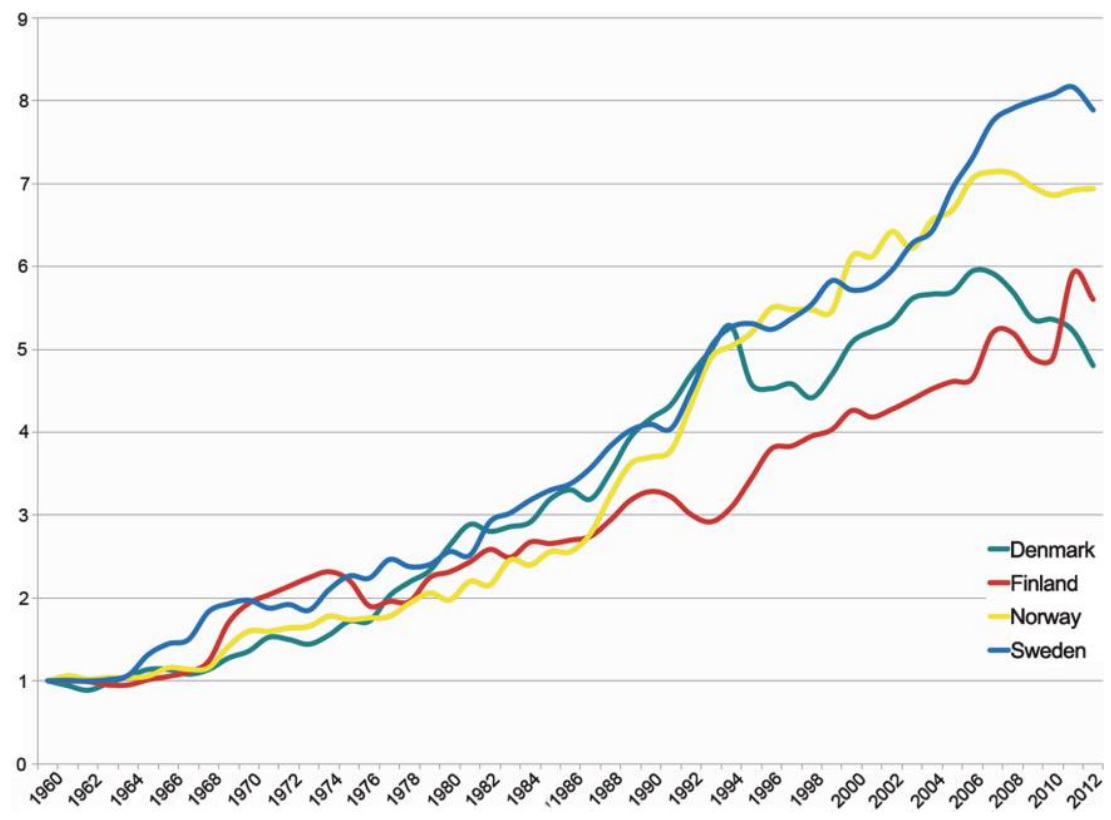

FIG. 20.-Standardized assault rates per 100,000 population, four Scandinavian countries, 1950-2012. Sources: 1950-2010: von Hofer et al. (2012, table 2); 2011-12: data provided by Tapio Lappi-Seppälä. Rates have been standardized using assault rates in 1960 as bases valued as one. The figure shows trends in each country relative to its starting point. 


\section{Why Apparent Rises in Violent Crime Are Misleading}

Changes in cultural thresholds of tolerance, victim reporting of incidents, and police recording of crimes are why violent crime rates appear, misleadingly, to be rising in some developed Western countries. In this section, I explain why the true incidence of violent crime is highly unlikely to be increasing in places where homicide rates are falling and briefly summarize evidence that suggests that apparent rises are artifacts of other social phenomena.

Nonlethal violence should be probabilistically associated with lethal violence in the same way that traffic deaths are with vehicle miles driven. Both sets of outcomes are products of the law of large numbers. In a particular place and period, 100,000 potentially violent incidents should produce predictable numbers of injuries and deaths in the same way that 100 million motor vehicle miles driven produce predictable numbers of traffic injuries and deaths.

Traffic injury and death rates per 100 million miles driven change slowly. They are probabilistic outcomes of driving skills, highway engineering, automotive design, medical trauma care, and random chance. With so many people driving so many kinds of vehicles on so many types of roads in any particular country, it would be astonishing if injury and death rates changed significantly from year to year. They have been gradually declining in the United States since the 1960s because all the factors that contribute to them have been changing in ways that reduce the incidence of accidents. Between 1981 and 2011, death rates fell by 0.03 percent per year (National Highway Traffic Safety Administration 2012, table 1). All developed countries including the United States have strengthened driver training requirements and targeted drunken driving; social norms about drinking and driving have changed; year by year, often under governmental mandates, automotive engineering changes have made cars safer; highway safety engineering has steadily improved; and the quality of treatment of traumatic injuries has improved. Without those changes, there is no reason to suppose that base rates of deaths and injuries would have changed at all.

And so it should be with homicide and nonlethal violence (e.g., Harris et al. 2002). Deaths should be probabilistically associated with the total number of potentially violent incidents. Franklin Zimring (1972) demonstrated this four decades ago in an article tellingly entitled "The Medium Is the Message: Firearm Caliber as a Determinant of Death 
from Assault." To investigate whether firearms affect the outcomes of violent crimes, he examined Chicago police reports for violent incidents in the late 1960s. He found that the likelihood of death occurring was probabilistically related to the tools available to an assailant. All else about an incident being equal, hands are less lethal than knives, which are less lethal than small-caliber firearms, which are less lethal than large-caliber firearms.

The data discussed in Section II demonstrate the probabilistic relationship between lethal and nonlethal violence in the English-speaking countries and demonstrate the existence of declining homicide rates in the Scandinavian countries. Baumer and Wolff (2014) and LappiSeppälä and Lehti (2014) demonstrate the existence of declining homicide rates in all developed Western countries. Nonlethal violence rates should be declining everywhere but appear in some places not to be. Either the law of large numbers does not apply in Scandinavia and in some other developed Western countries or the data are misleading.

The data are misleading. The fundamental reason is that there have been major shifts in cultural thresholds of tolerance of violence. One manifestation of this is that victims report larger percentages of incidents to the police. Victimization surveys almost always ask victims whether they have reported incidents to the police. In the United States and England and Wales, substantial increases in victim reporting have occurred for all offenses since the mid-1980s, but especially for sexual offenses and violence.

The most comprehensive and sophisticated analysis of NCVS data on victim reporting concluded that changes in victim reporting have led to substantial underestimates of the decline in the incidence of crime in the United States since 1991: "According to UCR data on nonlethal serious violence (i.e., rape, robbery, and aggravated assault), the number of violent crimes in the United States decreased by about 27 percent from 1991 to 2005 . However, the NCVS suggested a much larger decrease for these same crimes-about 51 percent" (Baumer and Lauritsen 2010, p. 173). Because the point is so important, I quote their main findings:

The overall empirical pattern that emerged from our research indicated that ... an apparent widespread and important increase can be observed in the likelihood of police notification in the United States during the past 30 years. This increase seems to have been led by a rise in reporting for sex offenses and family vi- 
olence, but we also observed significant increases in police notification since the early 1970s for burglary and motor vehicle theft as well as from the mid-to-late 1980s for nonsexual assaults, violence against both men and women, larceny, stranger and non-stranger assaults, [and] robberies committed by non-strangers. (P. 173)

No comparably sophisticated analysis of British Crime Survey data has been published. Responses to questions about reporting to the police since 1981, however, show substantial increases, especially for violence. Figure 21 shows relatively little change in victim reporting for burglary and motor vehicle theft but-especially relative to the 1981 base year-large ones for theft, minor assault (little or no injury), serious assaults (injury), and domestic violence (Chaplin et al. 2011, table 2.11). For domestic violence incidents, reporting to the police doubled, increasing from 20 percent in 1981 to 39 percent in 2010/11 and reaching 47 percent in 2009. Reporting of thefts, minor assaults, and serious assaults increased by half over the entire period and in some intervening years by more.

Comparably long-term, representative annual victimization surveys with large sample sizes are available in few other countries. Scandinavian countries are among them. There, as Kivivuori (2014) shows, victim reporting to the police has substantially increased since the early 1990s.

A second, multiplicative manifestation of the change in cultural thresholds is that the police record as crimes more of the incidents that come to their attention. This can happen as a matter of policy decisions or as a matter of unplanned - and unrecognized - changes in practice. Police in English-speaking countries traditionally operated output recording systems; a reported incident was recorded as a crime only if the police decided that the allegations were "founded," that is, if they satisfied legal criteria. An "unfounded" reported incident was not recorded as a crime. Input systems record reported incidents without independent confirmation by the police that a crime occurred. Not surprisingly, crime rates are higher in jurisdictions with input systems (Aebi 2008, 2010; Harrendorf 2012).

A number of countries have recently purposely switched from output to input recording systems. The 2002-3 English shift, which I discussed earlier, was predicted to increase crime rates generally but especially for violence (Simmons and Dodd 2003; Hough et al. 2005). As figure 17 shows for robbery, that is what happened. The principal 


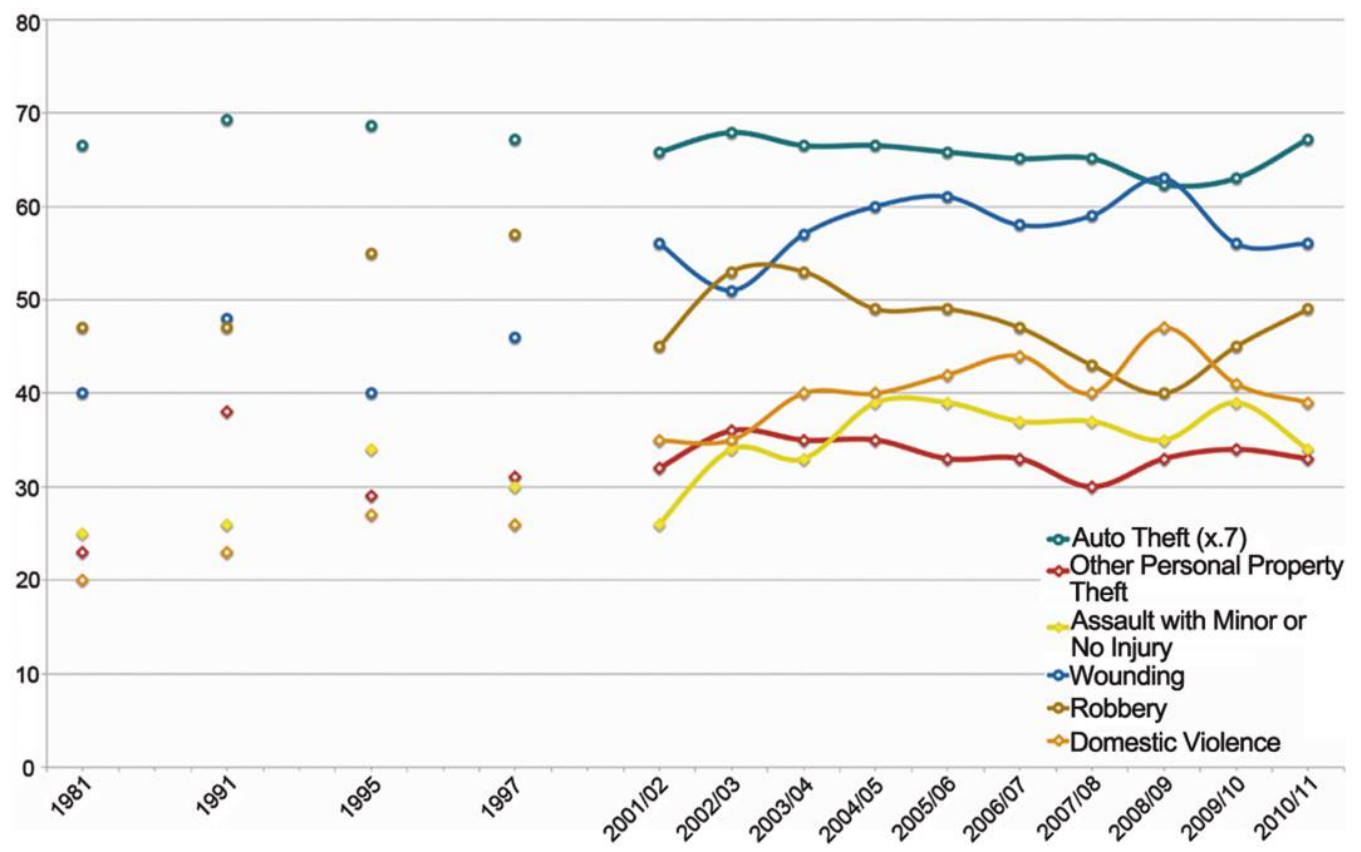

FIG. 21.-Percentages of respondents reporting victimization to the police, six offenses, England and Wales, 1981-2010/11. Source: Chaplin et al. (2011, table 2.01) 
explanation for such shifts is that politicians want more incidents to be officially counted as crimes.

Police themselves, however, are no less likely than anyone else to be affected by changing cultural thresholds of tolerance. An English example is illustrative. Table 2 shows absolute numbers of the four most violent crimes recorded by the police between 1991 and 2001: murder, attempted murder, threat or conspiracy to murder, and "wounding or endangering life." ${ }^{10}$ Panel A shows an upward trend in homicide from 669 deaths in 1991 to 850 in 2001 -a 25 percent increase, though totals in the other intervening years were significantly lower. The 2001 increase is partly attributable to the Harold Shipman killings. Even if we take the 2001 rate at face value, the increase is much lower than for other offenses. The number of attempted murders increased by 50 percent, the number of threats and conspiracies by 250 percent, and the number of woundings and endangerments by more than 70 percent.

That English recording pattern is evidence of unconscious bracket creep. If homicide has a probabilistic relationship to the most serious other forms of violence, the increases should have been comparable for each. Instead, year by year, the relationship between murder and other forms of serious violence became increasingly attenuated. This can be seen in panel B. It shows changing ratios of homicides to various combinations of serious violent offenses. The first row, for example, shows the total numbers each year of murders and attempted murders. The second row shows the percentages of those offenses that were murders. From 1991 to 2001 the homicide proportion fell modestly, from 58.4 to 54.6 percent. That is not enough of a change to support any strong inference. The criteria for recording a crime as an attempted murder appear not to have changed much or at all.

It is otherwise for the other offense groupings, as rows 4 and 6 of panel B show. Among offenses recorded as murders, or as attempts, threats, or conspiracies to murder, the murder proportion fell from 12.6 to 5.4 percent, more than halving. When all serious violent offenses are considered, the homicide proportion nearly halved, falling from 4.7 to 2.7 percent.

There are a number of reasons why the proportion of deaths among

${ }^{10}$ The table stops in 2001 because the input recording system that took effect in 2002 was predicted to have substantial but unknown effects on recording patterns, especially for violence. 
TABLE 2

England and Wales, Ratios of Murders to Other Violent Recorded Offences, 1990-2000/2001

\begin{tabular}{|c|c|c|c|c|c|c|c|c|c|c|c|c|c|}
\hline & 1990 & 1991 & 1992 & 1993 & 1994 & 1995 & 1996 & 1997 & $1997 / 98$ & 1998/99 & $1998 / 99^{*}$ & $\begin{array}{l}1999 / \\
2000^{*}\end{array}$ & $\begin{array}{l}2000 / \\
2001^{*}\end{array}$ \\
\hline & \multicolumn{13}{|c|}{ A. Recorded Violent Crimes } \\
\hline 1. Murder & 669 & 725 & 687 & 670 & 726 & 745 & 679 & 739 & 748 & 750 & 750 & 766 & 850 \\
\hline 2. Attempted murder & 476 & 555 & 568 & 661 & 651 & 634 & 674 & 652 & 661 & 676 & 676 & 750 & 708 \\
\hline $\begin{array}{l}\text { 3. Threat/conspiracy to } \\
\text { murder }\end{array}$ & 4,162 & 4,712 & 5,487 & 5,638 & 6,844 & 7,044 & 8,533 & 9,340 & 9,661 & 11,112 & 11,212 & 13,434 & 14,064 \\
\hline \multirow[t]{2}{*}{ 4. Wounding/ endangering life } & 8,920 & 9,408 & 10,741 & 10,701 & 11.033 & 10,445 & 12,169 & 12,531 & 12,833 & 13,960 & 14,006 & 15,135 & 15,662 \\
\hline & \multicolumn{13}{|c|}{ B. Ratios of Murders to Other Violent Crimes } \\
\hline Total $1+2$ & 1,145 & 1,280 & 1,255 & 1,331 & 1,377 & 1,379 & 1,353 & 1,391 & 1,409 & 1,426 & 1,426 & 1,516 & 1,558 \\
\hline $1 \div(1+2)$ & .584 & .566 & .547 & .503 & .527 & .540 & .502 & .531 & .531 & .526 & .526 & .505 & 546 \\
\hline Total $1+2+3$ & 5,307 & 5,992 & 6,742 & 6,969 & 8,221 & 8,423 & 9,886 & 10,731 & 11,070 & 12,538 & 12,638 & 14,950 & 15,622 \\
\hline $1 \div(1+2+3)$ & .126 & .121 & .102 & .096 & .088 & .088 & .069 & .069 & .068 & .060 & .059 & .081 & .054 \\
\hline Total $1+2+3+4$ & 14,227 & 15,400 & 17,483 & 17,670 & 19,254 & 18,868 & 22,055 & 23,262 & 23,903 & 26,498 & 26,644 & 30,085 & 31,284 \\
\hline $1 \div(1+2+3+4)$ & .047 & .047 & .039 & .038 & .038 & .039 & .031 & .032 & .031 & .028 & .028 & .025 & .027 \\
\hline
\end{tabular}

SOURCE.-Home Office (2001, table 2.15).

* Per revised classification scheme. 
serious violent incidents might change. Just as changes in drivers' skills, drunk driving prevalence, automotive safety, highway engineering, and trauma care explain why highway injury and death rates have been declining, equivalent changes might be sought for serious violent incidents. Improvements in trauma care, for example, have made a huge difference in homicide rates over the past several hundred years and a significant one over the past 50 (Monkkonen 2001; Harris et al. 2002) but are unlikely to have caused major declines in deaths from intentional injuries in the past two decades. Changes in the technology of violence in England and Wales should have increased rather than decreased the proportion of fatal injuries; the prevalence of assaultive use of both guns and knives increased in England and Wales in the 1990s. ${ }^{11}$ There are no close equivalents to changes in driving skills, automotive safety engineering, and the other contributors to the drop in automobile fatalities.

The proportion of homicides among serious violent incidents in England and Wales declined in the 1990s because the criteria police used to classify incidents gradually changed. Shifts in cultural attitudes toward violence, equivalent to shifts in cultural attitudes toward drunk driving, are the likeliest reason. British police increasingly classified incidents as very serious violence that in earlier years they would not have.

Something similar happened with less serious violent incidents. English civil servants have provided detailed statistical evidence that recording of minor assaults by the police increased substantially after 2000. They attribute the increases to the changes in counting rules discussed above and also to police responses to politicians' insistence that greater attention be given to minor violence (Britton et al. 2012).

Similar things have happened in many countries. In the conclusion to a recent book on the "international crime drop," Jan van Dijk and colleagues observe,

In times of declining rates of crime, police forces are inclined to lower their thresholds for recording cases of less serious crime. Crime recording in our view tends to be counter-cyclical. This institutional mechanism seems to account for the remarkable divergences over the past ten or fifteen years between survey results on assault and police figures on less serious violent crime in the US,

${ }^{11}$ Their use has fallen significantly since 2000 (Chaplin et al. 2011). 
Canada, several Western European countries, and Australia/New Zealand. Almost everywhere a degree of statistical net widening seems to have taken place, which has inflated the police count of violent crime. In our view, police figures of violent crime have, in recent years, been increasingly inflated. (Van Dijk et al. 2012a, p. 305)

Police are no less likely to be affected by shifts in prevailing cultural attitudes than anyone else. They watch the same films and television programs, read the same electronic and print media, and are affected by the same changes in prevailing political and cultural attitudes. Declining tolerance of wrongdoing caused crime victims in the United States, England and Wales, and Scandinavia to become increasingly likely in recent decades to report incidents to the police. In the United States, the principal reasons why prison populations rose in the 1970s and 1980s were that police arrested more people, prosecutors pursued cases they previously would have dropped and drove harder plea bargains, and judges sentenced more people to prison and for longer times (Blumstein and Beck 1999). Only later, in the 1990s, were harsher sentencing laws the primary driver of prison population changes (Raphael and Stoll 2013; Travis and Western 2014, chap. 3). Those laws also, however, reflected heightened intolerance of wrongdoing and more punitive attitudes to it.

If crime victims, police choosing whom to arrest, prosecutors making case processing decisions, and judges deciding sentences became more punitive, it would be astonishing if police-recorded crimes were unaffected by the attitudinal shifts that led to those changes. A rising sea lifts all things that float, including police boats.

There are thus good reasons to believe that rising official rates of crime in some countries are artifacts of cultural changes and not of real increases in violent incidents. The important question then becomes, Why have the offense amplification processes described in the preceding paragraphs occurred later in the Scandinavian (and some other European) countries than in the English-speaking countries? No one has been asking that question, so there is little research I can draw on to suggest answers.

One general hypothesis is that some countries are experiencing delayed responses to the rising crime rates of the 1970s and 1980s. Structural and cultural characteristics of the English-speaking countries caused them to respond earlier and more harshly. Repressive attitudes 
may both have risen and abated earlier than elsewhere. Tapio LappiSeppälä (2008) identified risk factors that especially characterize English-speaking countries in explaining why imprisonment rates rose substantially in some countries in recent decades but not in others. These include conflict versus consensus political systems, politically accountable prosecution and judicial systems versus apolitical civil service ones, expert versus political influence on policy making, and low versus high levels of trust by citizens in fellow citizens and government. Relative to most developed Western countries, England and Wales, New Zealand, the United States, and parts of Australia fall into the first of each paired set of alternative characteristics. In each, crime control was an important partisan political issue in the 1980s and especially the 1990s. This led to adoption and application of repressive crime control policies (and, with them, steeply rising prison populations).

A second, related general hypothesis is that the changes in cultural attitudes that caused long-term violence rates to fall also exacerbated public anger and resentments when short-term rates rose. The massive economic, social, and political changes of recent decades that affected all developed countries caused a several-decade disruption in long-term crime trends, as wars historically have. The gradual changes in social attitudes and values that caused violence rates to decline over centuries also raised thresholds of intolerance. In the English-speaking countries, especially the United States and England and Wales, politicians harnessed public anger to personal and partisan ends. The results in both countries included overheated political rhetoric, adoption of harsh crime control policies, and rising prison populations (Tonry 2004a, 2004b, 2010; Downes and Morgan 2012).

In much of Europe, by contrast, politicians and civil servants attempted rationally and humanely to address the challenges posed by rising crime, increased numbers of cases, enlarged budgets, and overstretched facilities (Tonry 2004c, 2007; Lappi-Seppälä 2008). The English-speaking politicians acknowledged public anxiety and anger and, as David Garland (2001) argued, adopted severe expressive punishments in response. Politicians in some other countries attempted to manage and suppress public anger and anxiety. Scandinavian and some other European countries may now be experiencing the public upset that might have accompanied an immediate doubling or trebling of crime rates after the 1960s. Because crime rates rose gradually, and 
their practical consequences were managed effectively, in some countries public anxiety was delayed. It became manifest only during the recent decades of declining crime rates.

Delayed public anger and indignation about deviant behavior, leading to harsh attitudes and policies, have been documented in other settings. In each of three periods of alcohol and drug prohibition in the United States since 1850, the most punitive public attitudes, the harshest new laws, and the most aggressive enforcement practices occurred years after drug use peaked and began to decline. The leading drug policy historian, David J. Musto (1999), had an explanation. When drug use was not widely seen as a major problem, many people argued that it was not as dangerous as others believed and in any case was a private matter: in a free society, people should be able to do as they wish as long as they do not harm others. As drug use rose and its ill effects became more widely recognized, he argued, attitudes began to harden and prohibitionist sentiments became more prevalent. Social norms began to change and at a tipping point caused drug use to begin to decline. Fewer people used drugs partly because they feared legal consequences. Partly, however, they stopped because they came to believe drug use to be wrong. As the decline continued, attitudes became progressively harder. Few people any longer believed, or at least would publicly argue, that use of illicit drugs is acceptable or harmless.

This social consensus reinforced the decline in drug use, weakened opposition to harsh policies, and added a tone of fierce moralism to drug law enforcement. Musto also observed that attitudes began to soften during the first two prohibition eras, and policies and practices to moderate, 15-20 years after drug use began to fall. That model also fits the most recent "war on drugs." Drug use peaked in the late 1970s and early 1980s. The harshest policies were enacted between 1984 and 1996 (Tonry 2004b). A similar pattern characterizes American crime policy. Crime rates fell for 5 years after 1981, then rose until 1991, and have fallen almost continuously since. The harshest sentencing laws were enacted in the mid-1990s. As happened with drugs in the 1990s, much of the fervor has disappeared from the politics of crime and policies have begun to soften (Tonry 2013).

A third hypothesis is that distinctive cultural or political developments in some countries have caused crime to be treated as a substantively and symbolically more important issue in recent years, thereby exacerbating awareness of crime and deviance. One result is a process 
of amplification by which harms come to be seen as more serious than in earlier times. Since the late 1990s, sexual offenses in Scandinavian countries have received steadily increasing political and ideological attention (Skilbrei and Holmström 2011, 2013). In both political debates and the media, crime discourse in Scandinavia is increasingly victimcentered and moralistic (Tham et al. 2011). The recent emphases on victims and on sexual offenses may have made victims and police more sensitive than in earlier times to minor kinds of invasive behavior, citizens more likely to perceive incidents as assaultive when answering victimization surveys and to report incidents to the police, and police more likely to treat them as offenses. Selmini and McElrath (2014) show that sexual offense rates in Scandinavia continued rising long after they began to fall in many countries. Kangaspunta and Haen Marshall (2012) reviewed victimization survey data and police statistics on intimate violence in a number of countries. Surveys consistently showed declines in violence between intimates. Police statistics showed increases. They argued that increased recording of intimate violence has been influenced by worldwide campaigns to reduce violence against women. Van Dijk et al. (2012a, p. 305) suggest that this is a specific example of a more general mechanism of net widening by the police in a period when crime is falling.

The hypothesis that changes in cultural thresholds of tolerance of violence have amplified its salience is only recently becomingly recognized. The ideas that victim reporting and police recording change over time are well known and increasingly well documented. The more elusive idea that there are changes in cultural thresholds of tolerance, which are important contributors to higher victimization and crime rates, is less widely recognized. Kivivuori (2014) provides compelling evidence about it from the United States, England and Wales, France, and the Scandinavian countries.

\section{Making Sense of Declining Crime Rates}

Substantial changes in crime rates ought to be an important social indicator. Sharp rises or falls or changes in long-term trends should tell us things about the health of social systems or about the nature and effects of major secular changes. This is the kind of subject about which men and women from Mars would expect there to be a sizable and sophisticated literature. They would be disappointed. Durkheim 
(e.g., [1893] 1933) had insightful things to say about crime as an organic outgrowth of social systems and about changes in levels and types of crime over time, but relatively few theorists have added much that is useful to his analysis. Garland (1990) stimulated renewed interest in Norbert Elias's ([1939] 1978) theory of a civilizing process that unfolded in Europe from the Middle Ages to modern times, bringing with it greater attention to hygiene, growing fastidiousness in serving and eating meat, and reduced use and acceptance of violence. Eisner showed $(2003,2008)$ that Elias's ideas provide at least part of a plausible explanation for the centuries-long decline in homicide rates.

Much of the theoretical work on explanation of crime trends until recently has been pretty primitive. That was probably inevitable since even somewhat reliable cross-national data, pertaining mostly to wealthy developed countries, have only recently become available. Most theorizing as a result has had to be a priori. Two competing cross-national sets of theories contended: a "Durkheimian" anomie theory that modernization weakened primary social bonds and with them inhibitions against egoistic behavior ${ }^{12}$ and a Marxissant conflict theory that exploitative international patterns of economic development weakened social bonds and systems, and with that social control, especially in underdeveloped countries (Neuman and Berger 1988; LaFree 1999). Gary LaFree (2005), analyzing 45 years of homicide data from 34 countries, tested "modernization" and conflict theories. He concluded that homicide trends were becoming more similar in wealthy developed countries but not in less developed countries and concluded that an "elite convergence" was occurring.

The articles mentioned in the preceding paragraph are not, of course, the only ones on the subject, but they are among the most cited and they give a flavor of the nature of recent theorizing. ${ }^{13}$ They

\footnotetext{
${ }^{12}$ This is slightly odd. The assumption that modernization and urbanization bring heightened crime rates with them contradicts the well-known historic pattern that crime rates were typically lower in the emerging cities of the modern era than in the countryside (Eisner 2003, pp. 105-6). In another of his intellectual hats, Durkheim (1982) famously argued that crime is a necessary social construct that every society needs in order to reinforce core values. As societies change, the content of "crime" necessarily changes, but the concept would exist even in a society of saints. Thus as societies evolve, conceptions of crime should change, but the amount of "crime" should be more or less constant.

${ }^{13}$ Another recent theoretical approach has been to test crime trend hypotheses derived from etiological theories of crime. The study by Kivivuori, Savolainen, and Danielsson (2012) is an especially comprehensive example.
} 
and others like them have largely been passed by. The historical work on long-term trends was much less well known when they were written. As a result they sought short-term explanations to what we now know to have been only modulations in long-term trends. Likewise, the now sizable literature documenting parallelism in homicide trends in wealthy Western countries did not exist (e.g., Eisner 2008), so their authors could not have known about it.

The near-absence of a theoretical literature on crime trends is astonishing. Hundreds of thousands of people have spent their lives studying crime and criminal justice systems, but only comparatively few have seriously attempted to explain the most striking and consequential crime developments of the past 50 years: the steep increase in crime rates in all developed Western countries beginning in the 1960s and the steep decreases since the early 1990s.

The most persuasive theories are the simplest and hark back to the writing of Ted Robert Gurr, Roger Lane, and James Q. Wilson in the 1980s. All of them looked for explanations for the U- and reverse Jcurves in social and economic changes likely to have affected social control processes and shaped capacities for self-control. Eisner showed that homicide rates fell throughout western Europe more or less continuously from the late Middle Ages. The timing and trajectories of decline varied, but most regions converged on a rate of one per 100,000 inhabitants by the beginning of the nineteenth century and almost all reached it by the beginning of the twentieth. Eisner's (2003) early explanations drew elements from Elias's ideas about a "civilizing process." Later he focused on Max Weber's ideas about the influence of the Protestant Ethic in shaping norms and values (Eisner 2008). The relevant mechanisms included state formation with a state nearmonopoly on legal violence, creation of institutions and processes that obviated needs for self-help, urbanization, and increasing social interdependence (Johnson and Monkkonen 1996; Eisner 2003).

Ted Gurr and others (Gurr et al. 1977; Gurr 1981) showed that crime rates declined generally in major Western cities in the nineteenth century and the beginning of the twentieth. Gurr's major early works were written before Eisner's findings became known, and he therefore sought not to locate nineteenth-century developments into longer patterns but to explain developments in the period he studied. In retrospect his explanations fit well with Eisner's synthesis. The major contributing causes were increases in social control and self-control 
associated with industrialization, urbanization, modernization, and bureaucratization. The archetypal institutions socializing individuals into conformity included the public school, the newly invented criminal justice institutions, the factory, the army, and the bureaucratic institutions of the modernizing state. Lane's (1980, 1992) explanations focused on interdependence and the need for individuals to learn to function cooperatively. Wilson (e.g., Wilson and Herrnstein 1985) focused more on the normative underpinnings of cooperative behavior and found them in religious revivals in the nineteenth century that strengthened social and self-control by means of socialization into strengthened moral norms of right behavior. ${ }^{14}$

Put together, those accounts cumulate into an intuitively plausible story of how human beings at least in developed countries gradually became less larcenous and less violent. They do not explain what went wrong in the 1960s. Francis Fukuyama (1999) provides a plausible account. Postwar economic expansions produced prosperous and peaceable years in the 1950s. However, in short order came decolonization of most of Africa, much of the Caribbean, and parts of South America and the Middle East; the Vietnam War and youthful rebellions of the 1960s; the civil, women's, and gay rights movements; economic transformations including the OPEC oil embargos of the 1970s, massive economic restructuring, and globalization; and vastly increased movements of people between countries. In retrospect it was all too much to be absorbed in a short time. As Chinua Achebe (1958) described colonial Nigeria, Things Fall Apart. Crime rates rose as did support in many countries for neoliberal and xenophobic political movements. That harsh crime policies emerged in some countries is not surprising.

By the 1990s, however, in most wealthy developed countries the effects of the preceding decades' disruptions had largely been absorbed. Crime rates peaked and began what proved to be precipitate falls. The historic long-term trend resumed after a several-decade disruption.

Most of the theorizing by social scientists has largely missed the big

\footnotetext{
${ }^{14}$ This is not very different from how Eisner (2008, p. 270) summarized Weber's ideas: "Weber used the term Lebensfiibrung . . or conduct of life [to refer] to a much wider cultural script encompassing work, politics, beliefs, education, and individual character. These models of conduct of life become reinforced and stabilized through institutions such as schools, families, the church, and bureaucracies. In The Protestant Ethic and the Spirit of Capitalism Weber [(1930) 1982] argued that models of conduct of life can be enormously powerful forces that mold the details of daily action and shape the trajectories of economic life."
} 
picture by focusing only on the aberrational decades of the 1970s and 1980s and the subsequent steep declines. ${ }^{15}$ By doing so, they miss the significance of the long-term patterns. Graham Farrell and his colleagues (2014), for example, adopt primarily opportunity and routine activities explanations for the post-1960s crime rise. The argument is that rates rose because larger quantities of valuable portable goods were available to be stolen, fewer people were at home during the day to guard them, and more people moved in public places and thereby became more vulnerable to personal victimization. The post-1990 declines are posited to be the effect of situational crime prevention initiatives including, notably, automobile theft prevention hardware, greatly increased use of home security hardware, and a wide variety of target-hardening and guardianship-enhancing initiatives. There are two insuperable difficulties. One is that the routine activities arguments and the situational initiatives, though plausibly related to changes in burglary and theft rates, are impossibly hard to relate to changes in rates of lethal and sexual violence. Arguments can be made that reducing property crime rates through instrumental means might delay, alter, or prevent onset of criminal careers and thereby affect the incidence of other kinds of crimes. However, the notion that there is a sizable causal relation between involvement in stealing cars or committing burglaries and the incidence of rape or murder is not credible. The second problem is that homicide rates in developed countries have moved in parallel for 50 years. Take-up and timing of situational crime prevention initiatives have varied widely over time and space. They cannot be the independent variable that explains changes in homicide rates.

A separate set of theories focusing on the influence of economic variables suffers from similar problems. ${ }^{16}$ Efforts have been made to

\footnotetext{
${ }^{15}$ Farrell et al. (2014) identify 17 theories that have been offered to explain recently rising crime rates and evaluate them using four tests. These include that the theory has cross-national validity and must be reconcilable with the crime rate increases of the 1970s and 1980s. Only one theory passes all four tests.

${ }^{16}$ Dills, Miron, and Summers (2008, p. 3) tested all the prevailing American explanations for the fall in crime rates and found that none was generalizable crossnationally: "Based on this evaluation, we argue that economists know little about the empirically relevant determinants of crime. This conclusion applies both to policy variables like arrest rates or capital punishment and to indirect factors such as abortion or gun laws. The reason is that even hypotheses that find some support in U.S. data for recent decades are inconsistent with data over longer horizons or across countries. Thus, these hypotheses are less persuasive than a focus on recent U.S. evidence might suggest."
} 
explain property crime rates specifically and crime rates generally, and changes in them, on the basis of national differences in economic variables such as unemployment, inflation, and economic growth (e.g., Rosenfeld and Messner 2009; Buonanno, Drago, and Galbiati 2014; Rosenfeld 2014). Such variables may or may not explain marginal differences in property crime rates over time, or even cross-nationally, but by definition, differences in them cannot explain common crossnational trends in homicide and other violent crimes. The problem is the same as that confronting the opportunity theories: the causal chain from greater or lesser incentives to commit burglaries or thefts to commission of killings and rapes is impossible to draw. Deeper forces of causal cross-national salience are at work.

Finally, it is no longer reasonable even to hypothesize that crime patterns can be explained in terms of punishment policies or imprisonment rates, although many academics, especially economists, try to do so (e.g., Buonanno et al. 2011). Figure 1, showing nearly identical homicide and robbery patterns in the United States and Canada but stable Canadian imprisonment rates and an American quintupling, is but one of many demonstrations (e.g., Tonry 2007; Lappi-Seppälä 2008). The most exhaustive recent analyses reach the same conclusion (Baumer and Wolff 2014; Lappi-Seppälä and Lehti 2014).

Lane (1992, p. 33) rightly and presciently observed, at a time when American crime rates appeared to be rising inexorably, and when little information was available about crime patterns elsewhere, as follows:

That this is an international phenomenon suggests that most of the usual parochial explanations for rising crime, whether of the left or right, do not apply. It is important to stress that neither the decisions of the Supreme Court of the United States, the increasingly black complexion of American cities, nor our national gun culture have much to do with rising rates in Scandinavia or Australia. That the curve was down during the previous century suggests also that neither massive economic change, the disruption of traditional society, nor waves of immigration, all modern phenomena first experienced during the nineteenth century, can explain the upsurge either.

What are left to explain long-term and recent trends are broad-based theories of social control and self-control (e.g., Baumer and Wolff 2014; Eisner 2014). 
As was true in Europe beginning in the late Middle Ages, crime rates move to deep and broad social forces, and move in parallel, even if sometimes with lags. That is what happened with major Western cities in the nineteenth and twentieth centuries and in all developed Western countries from the 1960s to the 1990s. Since then, rates for all the traditional crimes of property and violence have fallen substantially in many countries. The appearance of recently rising rates of nonlethal violence in some European countries will in time be revealed as an illusion. If I am right, apparent increases in violent crime rates in Europe should soon peak and then fall, making it clear that trends are moving in parallel not only in the English-speaking countries but in all the Western world.

\section{APPENDIX}

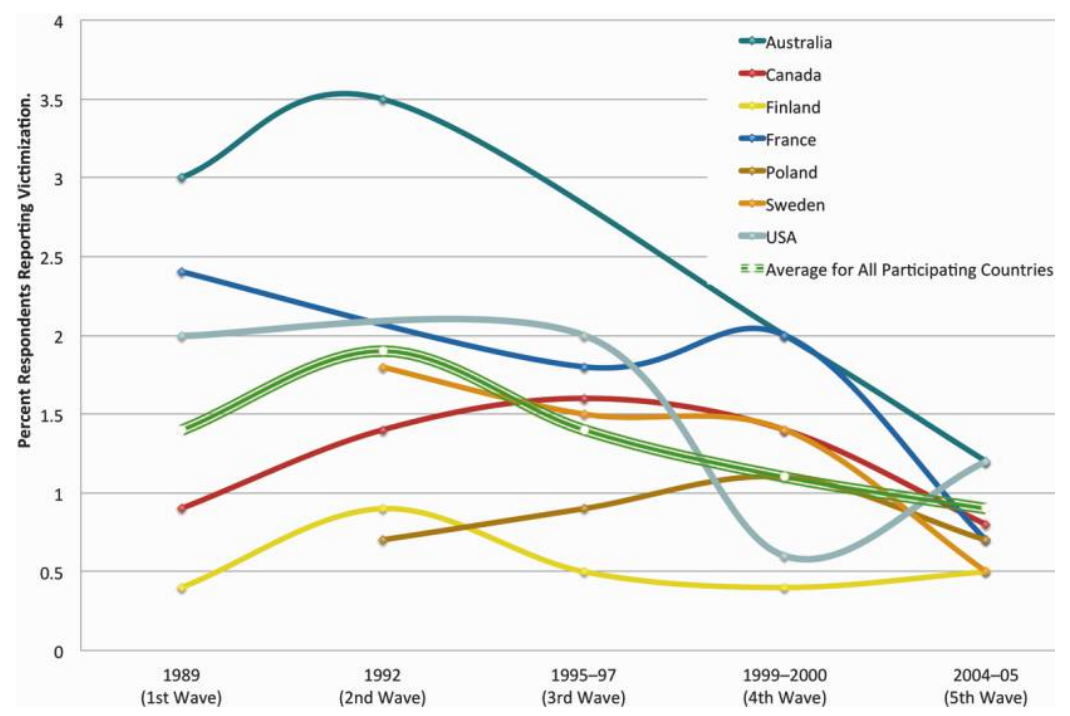

FIG. A1.-Percentages of respondents reporting automobile theft, ICVS, four or five waves, seven and all participating countries. Source: van Dijk et al. (2007, table 5). 


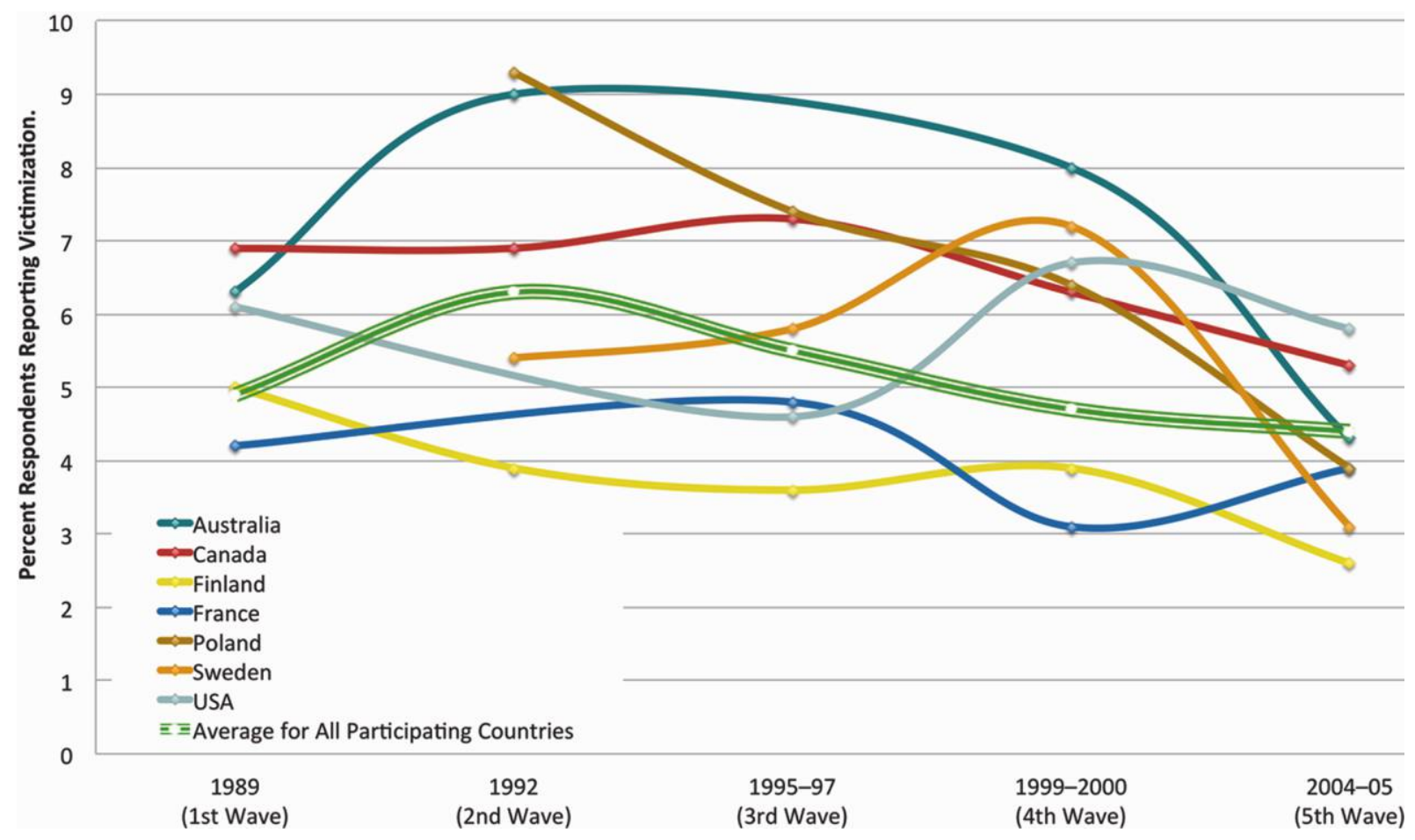

Fig. A2.-Percentages of respondents reporting personal theft, ICVS, four or five waves, seven and all participating countries. Source: van Dijk et al. (2007, table 5).

This content downloaded from 134.084.016.206 on September 28, 2016 14:47:06 PM

All use subject to University of Chicago Press Terms and Conditions (http://www.journals.uchicago.edu/t-and-c). 


\section{REFERENCES}

Achebe, Chinua. 1958. Things Fall Apart. London: Heinemann.

Aebi, Marcelo F. 2008. "Measuring the Influence of Statistical Counting Rules on Cross-National Differences in Recorded Crime." In Crime and Criminal Fustice Systems in Europe and North America, 1995-2004, edited by Kauko Aromaa and Markku Heiskanen. Helsinki: European Institute for Crime Prevention and Control and United Nations.

- 2010. "Methodological Issues in the Comparison of Police-Recorded Crime Rates." In International Handbook of Criminology, edited by Shlomo Giora Shoham, Paul Knepper, and Martin Kett. London: CRC Press.

Aebi, Marcelo F., et al., eds. 2010. European Sourcebook of Crime and Criminal Fustice Statistics - 2010. 4th ed. The Hague: Boom Juridische uitgevers.

Aebi, Marcelo F., and Antonia Linde. 2010. "Is There a Crime Drop in Western Europe?" European 7ournal of Criminal Policv and Research 16:251-77.

2012. "Crime Trends in Western Europe According to Official Statistics from 1990 to 2007." In The International Crime Drop: New Directions in Research, edited by Jan van Dijk, Andromachi Tseloni, and Graham Farrell. London: Palgrave Macmillan.

Alvazzi del Frate, Anna. 2010. "Crime and Criminal Justice Statistics Challenges." In International Statistics on Crime and Criminal Fustice, edited by Stefan Harrendorf, Markku Heiskanen, and Steven Malby. Helsinki: European Institute for Crime Prevention and Control and UN Office on Drugs and Crime.

Archer, Dane, and Rosemary Gartner. 1976. "Violent Acts and Violent Times: A Comparative Approach to Postwar Homicide Rates." American Sociological Review 41:937-63.

1984. Violence and Crime in Cross-National Perspective. New Haven, CT: Yale University Press.

Baumer, Eric P., and Janet L. Lauritsen. 2010. "Reporting Crime to the Police, 1973-2005: A Multivariate Analysis of Long-Term Trends in the National Crime Survey (NCS) and National Crime Victimization Survey (NCVS)." Criminology 48:131-85.

Baumer, Eric P., and Kevin T. Wolff. 2014. "The Breadth and Causes of Contemporary Trends in Cross-National Homicide Rates." In Why Crime Rates Fall and Why They Don't, edited by Michael Tonry. Vol. 43 of Crime and Fustice: A Review of Research, edited by Michael Tonry. Chicago: University of Chicago Press.

Blumstein, Alfred, and Allen J. Beck. 1999. "Population Growth in U.S. Prisons, 1980-1996." In Prisons, edited by Michael Tonry and Joan Petersilia. Vol. 26 of Crime and fustice: A Review of Research, edited by Michael Tonry. Chicago: University of Chicago Press.

Britton, Andrew, Chris Kershaw, Sarah Osborne, and Kevin Smith. 2012. "Underlying Patterns within the England and Wales Crime Drop." In The International Crime Drop: New Directions in Research, edited by Jan van Dijk, Andromachi Tseloni, and Graham Farrell. London: Palgrave Macmillan.

Brosig, Cheryl L., and Seth C. Kalichman. 1992. "Clinicians' Reporting of 
Suspected Child Abuse: A Review of the Empirical Literature." Clinical Psychology Review 12(2):155-68.

Buonanno, Paolo, Francesco Drago, and Roberto Galbiati. 2014. "Response of Crime to Unemployment: An International Comparison." Zournal of Contemporary Criminal 7ustice 30(1):29-40.

Buonanno, Paolo, Francesco Drago, Roberto Galbiati, and Giulio Zanella. 2011. "Crime in Europe and the United States: Dissecting the 'Reversal of Misfortunes." Economic Policy 7ournal 26:347-85.

Bureau of Justice Statistics. 1994. Criminal Victimization in the United States: 1973-1992 Trends. Washington, DC: US Department of Justice, Bureau of Justice Statistics.

Carcach, Carlos. 2005. "Crime and Punishment in Australia, 1980-2000." In Crime and Punishment in Western Countries, 1980-1999, edited by Michael Tonry and David P. Farrington. Vol. 33 of Crime and fustice: A Review of Research, edited by Michael Tonry. Chicago: University of Chicago Press.

Carson, E. Ann, and Daniela Golinelli. 2013. Prisoners in 2012-Advance Counts. Washington, DC: US Department of Justice, Bureau of Justice Statistics.

Chaplin, Rupert, John Flatley, and Kevin Smith, eds. 2011. Crime in England and Wales, 2010/11: Findings from the British Crime Survey and Police Recorded Crime. 2nd ed. London: Home Office Statistics.

Cockburn, J. S. 1991. "Patterns of Violence in English Society: Homicide in Kent, 1560-1985." Past and Present 130:70-106.

Dills, Angela K., Jeffrey A. Miron, and Garrett Summers. 2008. "What Do Economists Know about Crime?" NBER Working Paper no. 13759. Cambridge, MA: National Bureau of Economic Research.

Doob, Anthony M., and Cheryl Marie Webster. 2013. "'Truth in Sentencing' Act: The Triumph of Form over Substance." Canadian Criminal Law Review 17:365-92.

Downes, David, and Rod Morgan. 2012. "Overtaking on the Left: The Politics of Law and Order in the 'Big' Society." In The Oxford Handbook of Criminology, 5th ed., edited by Mike Maguire, Rod Morgan, and Robert Reiner. Oxford: Oxford University Press.

Durkheim, Emile. 1933. The Division of Labor in Society. Translated by George Simpson. New York: Macmillan. (Originally published 1893.)

- 1982. "Rules for the Distinction of the Normal from the Pathological." In The Rules of Sociological Method, translated by W. D. Halls. New York: Free Press.

Eisner, Manuel. 2003. "Long-Term Historical Trends in Violent Crime." In Crime and 7ustice: A Review of Research, vol. 30, edited by Michael Tonry. Chicago: University of Chicago Press.

- 2008. "Modernity Strikes Back? A Historical Perspective on the Latest Increase of Interpersonal Violence (1960-1990)." International fournal of Conflict and Violence 2:288-316.

- 2014. "From Swords to Words: Does Macro-Level Change in SelfControl Predict Long-Term Variation in Levels of Homicide?" In Why 
Crime Rates Fall and Why They Don't, edited by Michael Tonry. Vol. 43 of Crime and fustice: A Review of Research, edited by Michael Tonry. Chicago: University of Chicago Press.

Elias, Norbert. 1978. The Civilising Process. 2 vols. Translated by Edmund Jephcott. New York: Urizen. (Originally published 1939.)

Estrich, Susan. 1987. Real Rape. Cambridge, MA: Harvard University Press.

Farrell, Graham, Nick Tilly, and Andromachi Tseloni. 2014. "Why Did Crime Drop?" In Why Crime Rates Fall and Why They Don't, edited by Michael Tonry. Vol. 43 of Crime and Fustice: A Review of Research, edited by Michael Tonry. Chicago: University of Chicago Press.

Finkelhor, David, and Lisa Jones. 2006. "Why Have Child Maltreatment and Child Victimization Declined?" Zournal of Social Issues 62(4):685-716.

Fukuyama, Francis. 1999. The Great Disruption: Human Nature and the Reconstruction of Social Order. New York: Free Press.

Garbarino, James. 1989. "The Incidence and Prevalence of Child Maltreatment." In Family Violence, edited by Lloyd Ohlin and Michael Tonry. Vol. 11 of Crime and 7ustice: A Review of Research, edited by Michael Tonry and Norval Morris. Chicago: University of Chicago Press.

Garland, David. 1990. Punishment in Modern Society—a Study in Social Theory. Chicago: University of Chicago Press.

. 2001. The Culture of Control. Chicago: University of Chicago Press.

Goldberger, Arthur S., and Richard Rosenfeld, eds. 2008. Understanding Crime Trends: Workshop Report. National Research Council, Division of Behavioral and Social Sciences and Education, Committee on Understanding Crime Trends, Committee on Law and Justice. Washington, DC: National Academies Press.

Gurr, Ted Robert. 1981. "Historical Trends in Violent Crime: A Critical Review of the Evidence." In Crime and 7ustice: An Annual Review of Research, vol. 3, edited by Michael Tonry and Norval Morris. Chicago: University of Chicago Press.

- 1989. "Historical Trends of Violent Crime." In Violence in America, vol. 1, The History of Crime, edited by Ted Robert Gurr. Newbury Park, CA: Sage.

Gurr, Ted Robert, Peter N. Grabosky, and Richard C. Hula. 1977. The Politics of Crime and Conflict: A Comparative History of Four Cities. Beverly Hills, CA: Sage.

Harrendorf, Stefan. 2012. "Offence Definitions in the European Sourcebook of Crime and Criminal Fustice Statistics and Their Influence on Data Quality and Comparability." European Fournal of Criminal Policy and Research 18:23-53.

Harrendorf, Stefan, Markku Heiskanen, and Steven Malby, eds. 2010. International Statistics on Crime and Criminal fustice. Helsinki: European Institute for Crime Prevention and Control and UN Office on Drugs and Crime.

Harris, Anthony R., Stephen H. Thomas, Gene A. Fisher, and David J. Hirsch. 2002. "Murder and Medicine: The Lethality of Criminal Assault 19601999." Homicide Studies 6:128-66. 
Home Office. 2001. Criminal Statistics, England and Wales, 2000. London: Home Office, Research, Development, and Statistics Directorate.

Hough, Michael, Catriona Mirrlees-Black, and Michael Dale. 2005. Trends in Violent Crime since 1999/2000. London: King's College, Institute for Criminal Policy Research.

Johnson, Eric A., and Erik H. Monkkonen. 1996. "Introduction." In The Civilization of Crime: Violence in Town and Country since the Middle Ages, edited by Eric A. Johnson and Erik H. Monkkonen. Urbana: University of Illinois Press.

Kalichman, Seth C. 1999. Mandated Reporting of Suspected Child Abuse: Ethics, Law, and Policy. 2nd ed. Washington, DC: American Psychological Association.

Kangaspunta, Kristiina, and Ineke Haen Marshall. 2012. "Trends in Violence against Women: Some Good News and Some Bad News." In The International Crime Drop: New Directions in Research, edited by Jan van Dijk, Andromachi Tseloni, and Graham Farrell. London: Palgrave Macmillan.

Kivivuori, Janne. 2014. "Understanding Trends in Personal Violence: Does Cultural Sensitivity Matter?" In Why Crime Rates Fall and Why They Don't, edited by Michael Tonry. Vol. 43 of Crime and Fustice: A Review of Research, edited by Michael Tonry. Chicago: University of Chicago Press.

Kivivuori, Janne, Jukka Savolainen, and Petri Danielsson. 2012. "Theory and Explanation in Contemporary European Homicide Research." In The Handbook of European Homicide Research, edited by Marieke C. A. Liem and William Alex Pridemore. New York: Springer.

LaFree, Gary. 1999. "A Summary and Review of Cross-National Comparative Studies of Homicide." In Homicide: A Sourcebook of Social Research, edited by M. Dwayne Smith and Margaret A. Zahn. Thousand Oaks, CA: Sage.

_ 2005. "Evidence for Elite Convergence in Cross-National Homicide Victimization Trends, 1956 to 2000." Sociolooical Ouarterly 46:191-211.

Lane, Roger. 1980. "Urban Police and Crime in Nineteenth-Century America." In Crime and 7ustice: An Annual Review of Research, vol. 2, edited by Norval Morris and Michael Tonry. Chicago: University of Chicago Press.

- 1989. "On the Social Meaning of Homicide Trends in America." In Violence in America, vol. 1, The History of Crime, edited by Ted Robert Gurr. Newbury Park, CA: Sage.

. 1992. "Urban Police and Crime in Nineteenth-Century America." In Modern Policing, edited by Michael Tonry and Norval Morris. Vol. 15 of Crime and Justice: A Review of Research, edited by Michael Tonry. Chicago: University of Chicago Press.

Lappi-Seppälä, Tapio. 2008. "Trust, Welfare, and Political Culture: Explaining Differences in National Penal Policies." In Crime and 7ustice: A Review of Research, vol. 37, edited by Michael Tonry. Chicago: University of Chicago Press.

Lappi-Seppälä, Tapio, and Martti Lehti. 2014. "Cross-Comparative Perspectives on Global Homicide Trends." In Why Crime Rates Fall and Why They 
Don't, edited by Michael Tonry. Vol. 43 of Crime and fustice: A Review of Research, edited by Michael Tonry. Chicago: University of Chicago Press.

Lauritsen, Janet L., and Maribeth L. Rezey. 2013. Measuring the Prevalence of Crime with the National Victimization Survey. Washington, DC: US Department of Justice, Bureau of Justice Statistics.

Mastrofsky, Stephen D., and James J. Willis. 2010. "Police Organization Continuity and Change: Into the Twenty-First Century." In Crime and Fustice: A Review of Research, vol. 39, edited by Michael Tonry. Chicago: University of Chicago Press.

Minton, Todd D., and Daniela Golinelli. 2014. Fail Inmates at Midyear 2013Statistical Tables. Washington, DC: US Department of Justice, Bureau of Justice Statistics.

Monkkonen, Eric H. 1981. Police in Urban America, 1860-1920. Cambridge: Cambridge University Press.

- 2001. "New Standards for Historical Homicide Research." Crime, History and Society 5(2):7-26.

Muchembled, Robert. 2011. A History of Violence: From the End of the Middle Ages to the Present. Cambridge: Polity.

Musto, David J. 1999. The American Disease: The Origins of Narcotic Control. 3rd ed. New York: Oxford University Press.

Naess, Hans Eyvind. 1982. Trolldomsprosessene i Norge pa 1500-1600-tallet: En retts- og sosialhistorisk undersiikelse. Oslo: Universiteits Forlaget.

National Highway Traffic Safety Administration. 2012. 2011 Motor Vebicle Crashes: An Overview. Washington, DC: US Department of Transportation, National Highway Traffic Safety Administration.

Neuman, W. Lawrence, and Ronald J. Berger. 1988. "Competing Perspectives on Cross-National Crime: An Evaluation of Theory and Evidence." Sociological Ouarterly 29:281-313.

Office of National Statistics. 2013. Crime in England and Wales, Year Ending March 2013. London: Office of National Statistics.

Osterberg, Eva. 1996. "Criminality, Social Control, and the Early Modern State: Evidence and Interpretations in Scandinavian Historiography." In The Civilization of Crime: Violence in Town and Country since the Middle Ages, edited by Eric A. Johnson and Eric H. Monkkonen. Urbana: University of Illinois Press.

Osterberg, Eva, and Dag Lindstrom. 1988. Crime and Social Control in Medieval and Early Modern Swedish Towns. Uppsala: Academia Upsaliensis.

Pierotti, Rachael S. 2013. "Increasing Rejection of Intimate Partner Violence: Evidence of Global Cultural Diffusion.” American Sociological Review 78:240 65.

Pinker, Steven. 2011. The Better Angels of Our Nature: Why Violence Has Declined. New York: Viking.

Povey, David, and Julian Prime. 1999. Recorded Crime Statistics England and Wales: April 1998-March 1999. Home Office Statistical Bulletin 18/99. London: H.M. Stationery Office. 
Radzinowicz, Leon, and Roger Hood. 1986. The Emergence of Penal Policy in Victorian and Edwardian England. London: Stevens.

Raphael, Steven, and Michael A. Stoll. 2013. Why Are So Many Americans in Prison? New York: Russell Sage Foundation.

Reiss, Albert J., Jr. 1992. "Police Organization in the Twentieth Century." In Modern Policing, edited by Michael Tonry and Norval Morris. Vol. 15 of Crime and fustice: A Review of Research, edited by Michael Tonry. Chicago: University of Chicago Press.

Rosenfeld, Richard. 2014. "Crime and Inflation in Cross-National Perspective." In Why Crime Rates Fall and Why They Don't, edited by Michael Tonry. Vol. 43 of Crime and 7ustice: A Review of Research, edited by Michael Tonry. Chicago: University of Chicago Press.

- 2014. "The Crime Trends Roundtable." Criminologist 39(1).

Rosenfeld, Richard, and Steven F. Messner. 2009. "The Crime Drop in Comparative Perspective: The Impact of the Economy and Imprisonment on American and European Burglary Rates." British 7ournal of Sociology 60(3): $445-71$.

Selmini, Rossella, and Suzy McElrath. 2014. "Violent Female Victimization Trends in Europe, Canada, and the United States." In Why Crime Rates Fall and Why They Don't, edited by Michael Tonry. Vol. 43 of Crime and Fustice: A Review of Research, edited by Michael Tonry. Chicago: University of Chicago Press.

Simmons, Jon, and Tricia Dodd. 2003. Crime in England and Wales, 2002-2003. Home Office Statistical Bulletin 07/03. London: H.M. Stationery Office.

Skilbrei, May-Len, and Charlotta Holmström. 2011. "Is There a Nordic Prostitution Regime?" In Crime and Fustice in Scandinavia, edited by Michael Tonry and Tapio Lappi-Seppälä. Vol. 40 of Crime and fustice: A Review of Research, edited by Michael Tonry. Chicago: University of Chicago Press.

2013. Prostitution Policy in the Nordic Region: Ambiguous Sympathies. Farnham, Surrey, UK: Ashgate.

Smit, Paul R., Rinke R. de Jong, and Catrien C. J. H. Bijleveld. 2012. "Homicide Data in Europe: Definitions, Sources, and Statistics." In The Handbook of European Homicide Research, edited by Marieke C. A. Liem and William Alex Pridemore. New York: Springer.

Smith, Dame Janet. 2003. The Shipman Enquiry, Third Report: Death Certification and the Investigation of Deaths by Coroners. Presented to Parliament by the Secretary of State for the Home Department and the Secretary of State for Health by Command of Her Majesty. CM 5854. London: Home Office and Department of Health.

Spierenburg, Peter. 1996. "Long-Term Trends in Homicide: Theoretical Reflections and Dutch Evidence, Fifteenth to Twentieth Centuries." In The Civilization of Crime: Violence in Town and Country since the Middle Ages, edited by Eric A. Johnson and Eric H. Monkkonen. Urbana: University of Illinois Press.

2008. A History of Murder: Personal Violence in Europe from the Middle Ages to the Present. Cambridge: Polity. 
2012. "Long-Term Historical Trends of Homicide in Europe." In The Handbook of European Homicide Research, edited by Marieke C. A. Liem and William Alex Pridemore. New York: Springer.

Tham, Henrik, Anita Rönneling, and Lise-Lotte Rytterbro. 2011. "The Emergence of the Crime Victim: Sweden in a Scandinavian Context." In Crime and Justice in Scandinavia, edited by Michael Tonry and Tapio Lappi-Seppälä. Vol. 40 of Crime and fustice: A Review of Research, edited by Michael Tonry. Chicago: University of Chicago Press.

Tonry, Michael. 2004a. Punishment and Politics: Evidence and Emulation in the Making of English Crime Control Policy. Cullompton, Devon, UK: Willan.

- 2004b. Thinking about Crime: Sense and Sensibility in American Penal Culture. Oxford: Oxford University Press.

—. 2004c. "Why Aren't German Penal Policies Harsher and Imprisonment Rates Higher?" German Law Review 5:1187-1206.

- 2007. "Determinants of Penal Policies." In Crime, Punishment, and Politics in Comparative Perspective, edited by Michael Tonry. Vol. 36 of Crime and Justice: A Review of Research, edited by Michael Tonry. Chicago: University of Chicago Press.

- 2010. "The Costly Consequences of Populist Posturing: ASBOs, Victims, 'Rebalancing,' and Diminution of Support for Civil Liberties." Punishment and Society 12(4):387-413.

- 2013. "Sentencing in America, 1975-2025." In Crime and fustice in America, 1975-2025, edited by Michael Tonry. Vol. 42 of Crime and fustice: A Review of Research, edited by Michael Tonry. Chicago: University of Chicago Press.

Tonry, Michael, and David P. Farrington. 2005. "Punishment and Crime across Space and Time." In Crime and Punishment in Western Countries, 1980-1999, edited by Michael Tonry and David P. Farrington. Vol. 33 of Crime and Fustice: A Review of Research, edited by Michael Tonry. Chicago: University of Chicago Press.

Travis, Jeremy, and Bruce Western. 2014. The Growth of Incarceration in the United States: Exploring Causes and Consequences. National Research Council Committee on Law and Justice. Washington DC: National Academies Press. Truman, Jennifer L., and Michael Planty. 2012. Criminal Victimization, 2011. Washington, DC: US: Department of Justice, Bureau of Justice Statistics. van Dijk, Jan, and Andromachi Tseloni. 2012. "Global Overview: International Trends in Victimization and Recorded Crime." In The International Crime Drop: New Directions in Research, edited by Jan van Dijk, Andromachi Tseloni, and Graham Farrell. London: Palgrave Macmillan.

van Dijk, Jan, Andromachi Tseloni, and Graham Farrell. 2012a. "Conclusions-Understanding International Crime Trends: A Summing Up.” In The International Crime Drop: New Directions in Research, edited by Jan van Dijk, Andromachi Tseloni, and Graham Farrell. London: Palgrave Macmillan.

— eds. 2012b. The International Crime Drop: New Directions in Research. London: Palgrave Macmillan.

van Dijk, Jan, John van Kesteren, and Paul Smit. 2007. Criminal Victimisation 
in International Perspective: Key Findings from the 2004-2005 ICVS and EU ICS. The Hague: Netherlands Ministry of Justice.

von Hofer, Hanns. 2011. "Punishment and Crime in Scandinavia, 1750-2008."

In Crime and fustice in Scandinavia, edited by Michael Tonry and Tapio Lappi-Seppälä. Vol. 40 of Crime and Justice: A Review of Research, edited by Michael Tonry. Chicago: University of Chicago Press.

von Hofer, Hanns, and Tapio Lappi-Seppälä. 2014. "The Development of

Crime in Light of Finnish and Swedish Criminal Justice Statistics, Circa 1750-2010." European Fournal of Criminology 11(2):169-94.

von Hofer, Hanns, Tapio Lappi-Seppälä, and Lars Westfelt. 2012. Nordic Criminal Statistics, 1950-2010: Summary of a Report. 8th ed. Stockholm: Stockholm University, Kriminologiska institutionen.

Walmsley, Roy. 2013. World Prison Population List. 10th ed. Essex: International Centre for Prison Studies.

Weber, Max 1982. The Protestant Ethic and the Spirit of Capitalism. London: Routledge. (Originally published 1930, translated by Talcott Parsons, by Charles Scribner's Sons.)

Webster, Cheryl, and Anthony Doob. 2007. "Punitive Trends and Stable Imprisonment Rates in Canada." In Crime, Punishment, and Politics in a Comparative Perspective, edited by Michael Tonry. Vol. 36 of Crime and Justice: A Review of Research, edited by Michael Tonry. Chicago: University of Chicago Press.

Welsh, Brandon, and Mark H. Irving. 2005. "Crime and Punishment in Canada, 1981-1999." In Crime and Punishment in Western Countries, 1980-1999, edited by Michael Tonry and David P. Farrington. Vol. 33 of Crime and Justice: A Review of Research, edited by Michael Tonry. Chicago: University of Chicago Press.

Wilson, James Q. 1976. Thinking about Crime. New York: Basic Books.

Wilson, James Q., and Richard J. Herrnstein. 1985. Crime and Human Nature. New York: Simon \& Schuster.

Ylikangas, Heikki. 1976. "Major Fluctuations in Crimes of Violence in Finland:

A Historical Analysis." Scandinavian Fournal of History 1:81-103.

Zehr, Howard. 1975. "The Modernization of Crime in Germany and France, 1830-1913." Zournal of Social History 8:117-41.

1976. Crime and the Development of Modern Society: Patterns of Criminality in Nineteenth Century Germany and France. Totowa, NJ: Rowman \& Littlefield.

Zimring Franklin E. 1972. "The Medium Is the Message: Firearm Caliber as a Determinant of Death from Assault." Zournal of Legal Studies 1:97-123. 